\title{
Exclusion and Property Rules in the Law of Nuisance
}

\section{Citation}

Henry E. Smith, Exclusion and Property Rules in the Law of Nuisance, 90 Va. L. Rev. 965 (2004).

\section{Published Version}

http://www.virginialawreview.org/content/pdfs/90/965.pdf

\section{Permanent link}

http://nrs.harvard.edu/urn-3:HUL.InstRepos:10611774

\section{Terms of Use}

This article was downloaded from Harvard University's DASH repository, and is made available under the terms and conditions applicable to Other Posted Material, as set forth at http:// nrs.harvard.edu/urn-3:HUL.InstRepos:dash.current.terms-of-use\#LAA

\section{Share Your Story}

The Harvard community has made this article openly available.

Please share how this access benefits you. Submit a story.

\section{Accessibility}




\section{HEINONLINE}

Citation: 90 Va. L. Rev. 9652004

Content downloaded/printed from HeinOnline (http://heinonline.org)

Wed Oct 26 10:51:43 2011

-- Your use of this HeinOnline PDF indicates your acceptance of HeinOnline's Terms and Conditions of the license agreement available at http://heinonline.org/HOL/License

-- The search text of this PDF is generated from uncorrected OCR text.

-- To obtain permission to use this article beyond the scope of your HeinOnline license, please use:

https://www.copyright.com/ccc/basicSearch.do?

\&operation $=$ go\&search Type $=0$

\&lastSearch $=$ simple\&all=on\&titleOrStdNo $=0042-6601$ 


\section{VIRGINIA LAW REVIEW}

\begin{tabular}{lll}
\hline \hline VOLUME 90 & JUNE 2004 & NUMBER 4 \\
\hline \hline
\end{tabular}

\section{ARTICLE}

\section{EXCLUSION AND PROPERTY RULES IN THE LAW OF NUISANCE}

\section{Henry E. Smith*}

INTRODUCTION.

I. INFORMATION COSTS AND THE DELINEATION OF

ENTITLEMENTS

II. LOCATION IN THE LAW OF TRESPASS AND NUISANCE ............990

A. Trespass versus Nuisance ................................................... 992

B. Information Costs and the Nature of Nuisance Law..........996

1. Substantial Harm ............................................................. 997

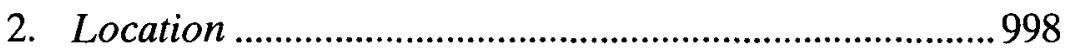

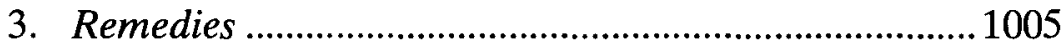

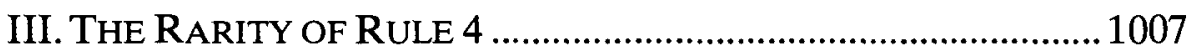

A. A Right to Pollute? ............................................................ 1011

B. Information Costs and Rights to the Flow of Air ............. 1016

C. Asymmetry and the Rule 4 "Gap" ..................................... 1019

IV. DELEGATION IN TORT AND PROPERTY LAW ..........................1021

A. Exclusion and Delegation in Tort Theory..........................1022

B. The Limits of Exclusion ..................................................... 1024

C. Exclusion and its Limits in the Law of Oil and Gas ........ 1027

D. The Limits of Injunctive Relief......................................... 1037

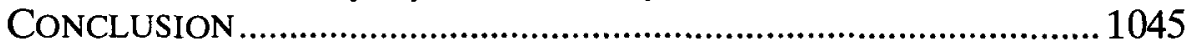

*Professor of Law, Yale Law School. E-mail: henry.smith@yale.edu. For comments and discussions, I would like to thank Ian Ayres, Bob Ellickson, Tom Merrill, Carol Rose, and participants at a faculty workshop at the Chicago-Kent College of Law. All errors are mine. 


\section{INTRODUCTION}

WUISANCE law holds a special place in the development of 1 law and economics. From Ronald Coase's article on social cost and continuing on through the present day, the analytics of the classic nuisance dispute have been the touchstone of economic theories of law. ${ }^{1}$ When the question is how to internalize pollution externalities or whether people bargain under the shadow of property rules and liability rules, economic models present the dispute as a conflict between plaintiff and defendant, and very often be-

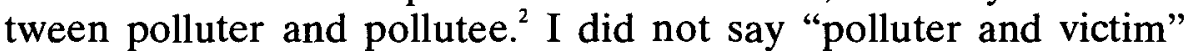
because one of the prime results of the economic analysis of law has been to cast doubt on ordinary notions of causation in favor of an economically more sophisticated view in which use conflicts exhibit symmetric causality: the pollutee's nose causes the use conflict just as much as the polluter's smokestack. Only an economist might be surprised that the world has stuck with ordinary notions of causation even in the face of the insights of Coase and his successors.

What these approaches to nuisance have in common is a very un-property-like view of entitlements. One reason that causation

\footnotetext{
${ }^{1}$ R.H. Coase, The Problem of Social Cost, 3 J.L. \& Econ. 1 (1960). For a sample bibliography of the vast literature on nuisance within the law and economics framework, see Timothy Swanson \& Andreas Kontoleon, Nuisance, 2 Encyclopedia of Law and Economics 380, 397-402 (Boudewijn Bouckaert \& Gerrit De Geest eds., 2000).

${ }^{2}$ Guido Calabresi \& A. Douglas Melamed, Property Rules, Liability Rules, and Inalienability: One View of the Cathedral, 85 Harv. L. Rev. 1089, 1115-17 (1972). Most liability rule literature employs nuisance as the leading example. For some recent examples, see, e.g., Ian Ayres \& Paul M. Goldbart, Optimal Delegation and Decoupling in the Design of Liability Rules, 100 Mich. L. Rev. 1, 2 (2001) [hereinafter Ayres \& Goldbart, Optimal Delegation] (detailing nuisance dispute between Polluter and Resident); Lucian Arye Bebchuk, Property Rights and Liability Rules: The Ex Ante View of the Cathedral, 100 Mich. L. Rev. 601, 602-03 (2001) (detailing dispute between Factory and Resort); Richard R.W. Brooks, The Relative Burden of Determining Property Rules and Liability Rules: Broken Elevators in the Cathedral, 97 Nw. U. L. Rev. 267, 291-92 (2002) (using "the familiar example of a dispute between a polluter and a resident who is affected by the pollution"); Louis Kaplow \& Steven Shavell, Property Rules Versus Liability Rules: An Economic Analysis, 109 Harv. L. Rev. 713,715 (1996) (arguing for liability rules in pollution context, as opposed to entitlements to tangible things); James E. Krier \& Stewart J. Schwab, Property Rules and Liability Rules: The Cathedral in Another Light, 70 N.Y.U. L. Rev. 440, 442 (1995) (using a pollution example in arguing for the importance of administrative costs and for a new type of liability rule).
} 
can be regarded as reciprocal in situations of land-use conflict is that Coase-and law-and-economics scholars more generallyassume that entitlements are decided on a use-by-use basis. ${ }^{3}$ In this, Coase and his successors reject the traditional idea of property as a right to a thing good against the world in favor of a realist picture of property as a collection of use rights, the so-called "bundle of sticks." If transaction costs were zero, the maximum value of production would be achieved through private bargaining regardless of the initial assignment of entitlements; when, however, transaction costs are positive, a collective decision as to who has the entitlement-each stick in the bundle-may be the final word and can affect overall efficiency. ${ }^{4}$ Thus, it would seem that when conflicts between actors and their activities arise, a court's job, particularly where transaction costs are high, is to decide which use shall prevail. The hallmark of nuisance law then becomes reasonableness, where each use must be justified in terms of a grand cost-benefit analysis. This has become the prevailing view among commentators, the Restatement, and treatises. ${ }^{5}$ But while many contemporary courts use a balancing approach, they often have paid no more than lip service to balancing and have instead hewed to a more traditional mode of analysis. ${ }^{6}$

Under the balancing approach, nuisance starts looking like core areas of tort law, particularly the law of negligence. The costbenefit approach to nuisance can take one of two forms, corresponding to two strains both in law and economics and in the law of torts itself. On the one side of the discussion are those like Richard Posner who advocate a "direct" cost-benefit analysis, akin to

\footnotetext{
${ }^{3}$ In Thomas W. Merrill \& Henry E. Smith, What Happened to Property in Law and Economics?, 111 Yale L.J. 357 (2001) [hereinafter Merrill \& Smith, What Happened to Property in Law and Economics?], Merrill and I pointed out the hyperrealist foundations of the law-and-economics approach to entitlements and drew on the framework of exclusion and governance discussed in Henry E. Smith, Exclusion versus Governance: Two Strategies for Delineating Property Rights, 31 J. Legal Stud. S453 (2002) [hereinafter Smith, Exclusion versus Governance], to suggest briefly that nuisance law has some exclusion-like elements. In this Article, I will explore the implications of the exclusion and governance framework, focusing on the theories of tort and nuisance law.

${ }^{4}$ Coase, supra note 1 , at 19.

${ }^{3}$ See infra Section II.B.

${ }^{6}$ See infra note 83 and accompanying text.
} 
the Learned Hand test for negligence.' Under this approach, conflicts between the uses proposed by the plaintiff and defendant are decided by finding out what combination of the two parties' activities and related precautions would maximize value. Not surprisingly, pro-negligence commentators favor direct balancing in nuisance. ${ }^{8}$

On the other side of the discussion are those such as Guido Calabresi who carry over cheapest-cost-avoider analysis into nuisance from their strict-liability approach in accident law. This analytical device is very often associated with strict liability, under which courts would not try to solve the allocation problem directly. ${ }^{9}$ Instead, taking a more indirect approach, courts in cheapest-cost-avoider mode would perform a higher-order analysis of which "activity" can more cheaply gather information about the benefits and costs of activities and act on that information. By placing liability on this "cheapest cost-avoider," courts can move society closer to optimal resource allocation because the liable party will weigh the costs of taking precaution (including foregoing some or all of the activity) against the expected liability and choose the most cost-effective combination of activity and precaution. The cheapest-cost-avoider approach is more indirect than the balancing espoused by Learned Hand and Richard Posner in that it chooses the chooser but leaves the first-order choice of whether the activity is worth its costs to the one on whom liability has been placed.

${ }^{7}$ United States v. Carroll Towing Co., 159 F.2d 169, 173 (2d Cir. 1947); see, e.g., William M. Landes \& Richard A. Posner, The .Economic Structure of Tort Law 29192 (1987); Richard A. Posner, A Theory of Negligence, 1 J. Legal Stud. 29, 32-33 (1972).

${ }^{8}$ See Richard A. Posner, Economic Analysis of Law 62 (6th ed. 2003) ("The alternative to absolute rights is balancing, and is the approach taken by the most important common law remedy for pollution, which is nuisance, the tort of interference with the use or enjoyment of land. The standard most commonly used for determining nuisance is unreasonable interference, which permits a comparison between (1) the cost to the polluter of abating the pollution and (2) the lower of the cost to the victim of either tolerating the pollution or eliminating it himself. This is an efficient standard ....") (citations omitted).

${ }^{9}$ See, e.g., Guido Calabresi, The Costs of Accidents: A Legal and Economic Analysis 135-73, 261-63 (1970); Guido Calabresi \& Jon T. Hirschoff, Toward a Test for Strict Liability in Torts, 81 Yale L.J. 1055, 1060 (1972); Harold Demsetz, When Does the Rule of Liability Matter?, 1 J. Legal Stud. 13, 27-28 (1972). Commentary employing cheapest-cost-avoider analysis is voluminous. 
Both the direct Learned Hand-style approach and the cheapestcost-avoider analysis maintain the Coasean procedure of assigning entitlements as an ongoing list of use rights-building up the property bundle stick-by-stick. Indeed, if there is one thing upon which commentators seem to agree, it is that the standard for nuisance law should be assimilated to that of accident law. With a negligence test, parties would gain rights to activities by having a court establish that the activity is "reasonable," in the sense that it passes a cost-benefit test. ${ }^{10}$ If carried over to nuisance, this means that if activities-accompanied by cost-effective precautions-are worth more than the damage they cause, then they do not generate liability. Cheapest-cost-avoider analysis likewise assumes that entitlements are built up use-by-use, stick-by-stick. On the cheapest-costavoider view, parties would gain rights by being at the other end of a conflict from a party deemed to be a cheapest cost-avoider. Thus, if polluters are-as they often but not necessarily are-found to be the cheapest cost-avoiders in pollution situations, then the pollutee-resident will gain a right to be free from pollution. ${ }^{11}$ Under either of these two strains of nuisance analysis, the question has shifted from a traditional one of whose (antecedent) rights have been violated to an evaluation of activities-either their direct merits or their indirect cost-avoiding capacities-and consequently involves assignment of sticks in a bundle of entitlements. When a new use conflict arises, we move on to the next analysis and a fresh determination of who gets the new "stick" in their evolving bundles. $^{12}$

\footnotetext{
${ }^{10}$ Negligence theorists bemoan the retention of strict liability for invasions of rights in land instead of developing a single overarcling negligence standard that would apply in nuisance. See, e.g., Louise A. Halper, Untangling the Nuisance Knot, 26 B.C. Envtl. Aff. L. Rev. 89, 115-16 (1998).

${ }^{11}$ Compare Calabresi, supra note 9, at 254 (arguing that factory is the "best briber"), with Frank I. Michelman, Pollution as a Tort: A Non-Accidental Perspective on Calabresi's Costs, 80 Yale L.J. 647, 667-68 (1971) ("The most sweeping arguments for strict liability and liberal 'standing' criteria would apparently assume that polluters are nearly always the cheapest cost-avoiders, and while that assumption may have a certain gross plausibility for the whole universe of pollution-nuisance cases, there is no a priori reason for believing it to be valid in any particular case.").

${ }^{12}$ See, e.g., George P. Smith \& Griffin W. Fernandez, The Price of Beauty: An Economic Approach to Aesthetic Nuisance, 15 Harv. Envtl. L. Rev. 53, 53 (1991) ("Scholars have characterized the history of nuisance as the articulation and valuation of a 'bundle of rights' pertaining to the enjoyment of real property."); cf. J.E. Penner,
} 
But this is not at all how the law usually proceeds. Courts routinely speak in terms of who has injured whom, and they often ask simply whether the plaintiff's rights have been invaded. ${ }^{13}$ And much of the time in nuisance cases this inquiry involves a search for physical invasions flowing from the defendant's to the plaintiff's land. Indeed, commentators in the corrective justice tradition tend to emphasize the physical invasion aspect of nuisance to an even greater extent than the weight of current American case law, with the latter's tentative steps towards balancing. ${ }^{14}$ In light of these conflicting strains of thought about nuisance, the law of nuisance is widely regarded as a "mess," 15 a "wilderness' of law,"16 a "legal garbage can," 17 and a "mystery." 18

In this Article, I propose that nuisance is not so much a mess or a mystery as a hybrid between different methods of delineating rights, and that this hybrid reflects the information costs incurred in employing these strategies. Information costs go a long way toward explaining why and how nuisance law rests on a foundation of exclusionary property rights-and, in particular, why physical invasions are important in nuisance law. Information costs include the costs of generating information about rights in the process of de-

Nuisance and the Character of the Neighbourhood, 5 J. Envtl. L. 1, 14-25 (1993) [hereinafter Penner, Nuisance and the Character of the Neighbourhood] (explaining and criticizing the "bundle of rights" view).

${ }^{13}$ The approach based on invasion of rights was at its zenith in the nineteenth century, but still retains some force. See, e.g., Robert G. Bone, Normative Theory and Legal Doctrine in American Nuisance Law: 1850 to 1920, 59 S. Cal. L. Rev. 1101 (1986); Thomas W. Merrill, Trespass, Nuisance, and the Costs of Determining Property Rights, 14 J. Legal Stud. 13, 26-35 (1985) (documenting four tests for nuisance and their continuing use); see also infra notes $84-88$ and accompanying text (referring to tests distinguishing trespass and nuisance).

${ }^{14}$ See, e.g., Richard A. Epstein, Nuisance Law: Corrective Justice and Its Utilitarian Constraints, 8 J. Legal Stud. 49, 53-56 (1979) [hereinafter Epstein, Nuisance Law]. For an even more uncompromising defense of the English bright-line property-based approach to nuisance against some recent developments, see Penner, Nuisance and the Character of the Neighbourhood, supra note 12.

${ }^{15}$ Halper, supra note 10 , at 130.

${ }^{16}$ H.G. Wood, A Practical Treatise on The Law of Nuisances in Their Various Forms; Including Remedies Therefor at Law and in Equity iii (San Francisco, Bancroft-Whitney 3d ed. 1893).

${ }^{17}$ William L. Prosser, Nuisance Without Fault, 20 Tex. L. Rev. 399, 410 (1942).

${ }^{18}$ Warren A. Seavey, Nuisance: Contributory Negligence and Other Mysteries, 65 Harv. L. Rev. 984, 984 (1952) (quoting Delaney v. Pliilhern Realty Holding Corp., 21 N.E.2d 507, 510 (N.Y. 1939) (Crane, C.J., concurring)). 
lineating and publicizing them, as well as the costs incurred by third parties in processing information about the scope, nature, and validity of those rights. I will argue that giving owners a right to exclude from a thing good against the world is a rough but low-cost method of generating information that is easy for the rest of the world to understand. These exclusionary rights can be justified on a number of grounds: libertarianism, autonomy, personhood, desert, and so on, but I will focus on an information-cost rationale for broad rights. It is often assumed that nonutilitarian theories always justify strong property rights, and that utilitarian theories inevitably undermine them. ${ }^{19}$ Both propositions are questionable, and this Article will focus on the second.

As for the first proposition-that nonutilitarian theories uniquely explain strong property rights-I suggest that these theories do not always tell us the exact form property rights should take and, in particular, how and why property rights tend to encompass as many uses as they do. Imagine a world in which each resource has exactly two known uses. In such a world, one could advance liberty, personhood, and so on by specifying rights over the two uses, or perhaps over just one of them. To what extent these values could be vindicated by giving people rights in activities (as in the core of tort law) rather than a right to exclude others from "things" remains an open question. What degree of control over the world's resources would be required to vindicate the values at the root of the property system, and could this control be specified in terms of rights to engage in tort law's "activities" rather than property-like rights to "things?" As I will argue, information costs do not fully explain why we have the entitlements we have, but they do help explain why entitlements are exclusionary in many, but not all, contexts.

The information-cost theory can also be brought to bear on the second proposition-that law and economics, or any utilitarian analysis, will favor narrow use rights-and can bridge some of the gap between utilitarian and corrective justice theories of nuisance and of torts more generally. Conventional utilitarian-style economic analysis furnishes little reason to think that conceptualizing property as the right to exclude the world from a thing makes any

\footnotetext{
${ }^{19}$ For typical discussions, see the sources cited in supra note 14.
} 
sense at all. In response to traditional concerns in property for investment, security, and internalization, an economic theory could advocate a tailored approach that would assign entitlements and liability according to the "goods" and "bads" associated with various activities. Resources would be no more than the backdrop of this use-by-use delineation, and a law of "things" would be largely superfluous. Notice, however, that this delineation is costly because it requires specification of informational variables, or "measurement proxies," that will isolate the various uses and help identify the value of each. ${ }^{20}$ In many cases, particularly where the gains from multiple use and the transaction costs of achieving coordination are high, it makes sense for the law to engage in precise tailoring. At the hypothetical extreme, the law would implement a list of use rights holding between all potential pairwise combinations of persons with respect to any (at least heretofore) conceivable activity that has any impact on anyone. The costs of this approach would be prohibitive, but it is the vision lurking behind the economic approach to tort, and especially nuisance, law.

Instead of this comprehensive approach, the law often grants an "owner" the right to exclude others from a resource or "thing." This type of legal arrangement relies on what I have called an $e x$ clusion regime. Under an exclusion regime, the law uses a rough informational variable or signal-such as entry-to define the right, and thus bunches together a range of uses that juries, judges, and other officials need never measure directly. The right to exclude is best understood as a gatekeeper right - the owner's right to determine the use of the thing, ${ }^{22}$ and is protected by common law

\footnotetext{
${ }^{20}$ This use of the words "measurement" and "proxy" is characteristic of neoinstitutional economics and especially of the work of Yoram Barzel, who points out that measurement is the operationalization of information. See Yoram Barzel, Measurement Cost and the Organization of Markets, 25 J.L. \& Econ. 27, 28 \& n.3 (1982).

${ }^{21}$ The right to exclude is especially important in property and some have argued that it is its essential feature. See, e.g., J.W. Harris, Property and Justice 13 (1996); J.E. Penner, The Idea of Property in Law 71 (1997) [hereinafter Penner, The Idea of Property]; Felix S. Cohen, Dialogue on Private Property, 9 Rutgers L. Rev. 357, 374 (1954); Thomas W. Merrill, Property and the Right to Exclude, 77 Neb. L. Rev. 730 (1998).

${ }_{22}^{2}$ See, e.g., Penner, The Idea of Property, supra note 21, at 29-30, 71; Merrill, supra note 21 , at 739 .
} 
actions such as ejectment, trespass, and nuisance..$^{23}$ Because such an exclusion regime builds on simple on/off signals such as boundary crossings, rights to exclude are typically protected with injunctions and supracompensatory damages. Exclusion is associated with what Guido Calabresi and A. Douglas Melamed termed "property rules," under which a remedy is strong enough to deter nonconsensual takings, as opposed to liability rules under which nonconsensual takings are allowed as long as officially determined compensation is paid..$^{24}$ From the perspective of judges and other officials, exclusion grants owners a gatekeeper right that protects the owners' interests in a wide and indefinite class of uses without the need ever to delineate-perhaps even to identify-those uses at all. Having a right to exclude from Blackacre, an owner can build on it, grow crops on it, park cars on it, and so on. This set of uses is indefinite and open-ended, and it need not be individually defined in advance.

Some of the uses may be prohibited under covenants or zoning, arrangements that suggest another mode for delineating rights. In contrast with exclusion, at the other end of the spectrum of delineation methods, resides a governance regime that focuses on proper use. The law-and-economics approach to nuisance-which advocates a reasonableness or cost-benefit inquiry into uses-is just such a governance regime. Thus, a prohibition on certain odors wafting from a factory at certain times and in certain directions is about a given class of uses, not simply an on/off question about whether a boundary has been crossed. Between these poles of exclusion and governance are various modes of delineating entitlements that differ in terms of how directly tied to uses-how precisely tailored-are the informational variables employed to police the rights.

${ }^{23}$ On trespass versus nuisance, see infra Section II.A. In the law of personal property, the right to exclude is vindicated through the actions of conversion, replevin, trover, detinue, trespass to chattels, and the various theft offenses.

${ }^{24}$ Calabresi \& Melamed, supra note 2, at 1092 (distinguishing property rules from liability rules in the domain of transferable entitlements); see also Henry E. Smith, Property and Property Rules, 79 N.Y.U. L. Rev. (forthcoming 2004) [hereinafter Smith, Property and Property Rules] (draft on file with author and Virginia Law Review Association) (explaining why exclusion is strongly associated with property rules). 
In concrete situations, the right to exclude requires a degree of deference-or "delegation"-to owners in their choice to exercise one or more of the indefinite set of use-privileges protected by the exclusion right. The law of trespass is the most deferential. Thus, if $A$ owns Blackacre and decides not to allow a neighbor to have a mobile home transported across it, $A$ can sue as trespassers those who may have very good, cost-justified reasons for wanting to move mobile homes across the land. Furthermore, $A$ may do so without having to show that the refusal was reasonable. ${ }^{25}$ The law of nuisance also requires deference to owners, but less consistently so.

Nuisance introduces elements of governance that require courts to directly evaluate uses. If odors waft over from neighboring Whiteacre, the owner of Whiteacre would, under the common law, normally be liable to $A$ without inquiry into whether the odorproducing activity is more important than $A$ 's use of his land. But the law of nuisance puts more of the direct evaluation of uses in judges' hands than does the law of trespass; thus, if the odors conform to reasonable use in the locality or are de minimis, no nuisance will be found. Under one approach, courts will refuse injunctions if the injunction would cause great waste and economic dislocation. ${ }^{26}$ In contrast, a purer exclusionary approach like that of trespass delegates this assessment-even the discovery-of uses to the owner by making her the gatekeeper through an exclusive right based on rough informational variables such as entry across a boundary.

In this Article, I will show that the information-cost theory can explain some otherwise very puzzling cases in which the law prefers exclusion but where conventional law and economics would lead one to expect a preference for a more tort-like evaluation of activities-governance, in terms of the proposed framework. In Part I, I further distinguish exclusion from governance and show how they work together to define entitlements in a way that takes

\footnotetext{
${ }^{25}$ For a dramatic recent example, see Jacque v. Steenberg Homes, Inc., 563 N.W.2d 154 (Wis. 1997) (upholding an award of punitive damages where only nominal compensatory damages were found), which I discuss further at notes 49-55 and accompanying text.

${ }^{26}$ The leading case is Boomer v. Atlantic Cement Co., 257 N.E.2d 870 (N.Y. 1970). I discuss Boomer, infra Section IV.D.
} 
information costs into account. In general, property and property rules are favored where the law reflects a second-order decision to delegate first-order information gathering and choice of use to an owner and to avoid official inquiry into the sphere of delegated choice. Part II will then show how the relationship of trespass and nuisance-including the association of property rules with trespass-is explained by the information costs associated with governance regimes. Even the nuisance disputes upon which Coase based his original discussion of social cost point strongly toward the important roles of location and exclusion in lowering the information costs associated with nuisance disputes. Part III will explain why plaintiffs are generally not permitted to invoke the law to force the polluter either to abate the nuisance or to shut down upon payment by the plaintiff of "damages" in the amount of the polluter's costs of doing so. The information-cost theory will help explain why such compensated injunctions-Guido Calabresi and A. Douglas Melamed's famous "Rule 4"-are not as common as one might expect under various theories of liability rules. Conventional liability rules that compensate victims for pollution with damages-Calabresi and Melamed's "Rule 2"- still capture the information-cost lowering benefits of the "thingness" of property entitlements, whereas Rule 4 undermines the basic exclusionary regime. Part IV will show that treating exclusion and governance as complementary elements in a system of entitlements not only furnishes a better descriptive theory, but also sharpens the most pressing normative issue in areas such as nuisance. Part IV explores the question of when the presumptive and foundational exclusion regime should give way to more nuanced tailoring through governance.

\section{INFORMATION COSTS AND THE DELINEATION OF ENTITLEMENTS}

Information costs play an important role in both torts and property, but it is widely assumed that the impact of such costs are similar in that they botli bear on the evaluation of competing and conflicting uses. In this Part, I argue that much of property law-and some of tort law-reflects a very different approach to information, one based on a strategy of delegating informational questions to owners by delineating exclusive rights to a thing, enforceable against all others. Upon this rough but basic exclusion strategy, fur- 
ther refinement and precision are sometimes achieved through a supplementary governance regime-a set of rules of proper use. It is these latter use rules that look more like realist, Coasean "property," but they are best seen as supplements to the rules of exclusive access that give the tort of trespass, property's basic protection, its distinctive, hard-edged character. ${ }^{27}$ Nuisance employs this exclusion regime when it comes to gross invasions of clear boundaries, but supplements the exclusion regime with fine-tuned governance rules. Exclusion and governance each have a distinctive set of costs and benefits, and, in this Part, I show that legal entitlements can be delineated in a low cost fashion if they rest on a foundation of exclusion supplemented by fine-tuning governance rules. Nuisance turns out to be an area of law in which the shift from one strategy to the other is especially pronounced.

Tort law is the regulation by courts of harmful activities. Although institutional constraints prevent courts from taking as comprehensive or as detailed a view of harmful interactions as can other officials, ${ }^{28}$ core tort law is all about proper use. In this respect it differs very much from core property law, which is, from a layman's perspective, about "things." 29 For a variety of reasons, law and economics tends to take a very realist view of property as a

${ }^{27}$ Coase treated property rights as lists of use rights rather than as rights to things. See Merrill \& Smith, What Happened to Property in Law and Economics?, supra note 3, at 369-71.

${ }^{28}$ Richard A. Epstein, Possession As the Root of Title, 13 Ga. L. Rev. 1221, 1222-23 (1979) [hereinafter Epstein, Possession] (arguing that because of courts' modest remedial powers their "definition of rights is therefore apt to be made along certain 'natural lines'; there will be broad general propositions that can apply to all against all, and there will be no reference to the numbers or formulas . . that can be generated by direct administrative controls, such as zoning"); Thomas W. Merrill \& Henry E. Smith, Optimal Standardization in the Law of Property: The Numerus Clausus Principle, 110 Yale L.J. 1, 62-63 (2000) [hereinafter Merrill \& Smith, Optimal Standardization in the Law of Property] (arguing that legislatures can provide comprehensiveness in devising new property forms better than can courts); see also Neil K. Komesar, Imperfect Alternatives: Choosing Institutions in Law, Economics, and Public Policy 7-8 (1994) (presenting a theory of comparative institutional choice centered on bias and expertise).

${ }^{29}$ Bruce A. Ackerman, Private Property and the Constitution 26-31, 97-103 (1977) (contrasting "scientific" perspective about the meaning of property as a bundle of rights with the "layman's" perspective that persists in thinking of property as rights to things); Merrill \& Smith, What Happened to Property in Law and Economics?, supra note 3 , at $357-58$. 
"bundle of sticks." ${ }^{30}$ In a manner similar to Hohfeldian analysis, law and economics breaks legal relations down into their smallest constituent parts but, unlike Hohfeld, then asks whether they serve efficiency and, occasionally, other goals such as fairness. ${ }^{31}$ Where property meets tort, this atomizing tendency is magnified since many areas of tort law, beginning with the paradigmatic problem of accidents, are naturally carved up into conflicting activities. To Coase and his successors, it was an easy step to see harmful interactions that come under the heading of "nuisance" in similar terms. Two activities conflict and the resolution, however effected and through whichever institutions, can be evaluated as to how well it promotes the efficient use of resources. Resource scarcity is reduced to a bilateral conflict over use, and rights to resources are conceptualized as being built up from the determinations in cases involving these conflicting uses. If $A$ is causing pollution that bothers $B$, the question is not who caused injury to whom but rather which activity is more valuable (or who is able to take precautions more cheaply), with that determination resulting in the entitlement (or liability) being assigned to the performer of that activity.

But property law speaks of the right to exclude the rest of society from a thing. To the legal economist thinking in tort mode, this is an unnecessary and unfortunate locution that only obscures what is really going on. For example, Coase disparaged analogies of

\footnotetext{
${ }^{30}$ See, e.g., Ackerman, supra note 29, at 26-29 (reporting that the bundle-of-rights conception of property is so pervasive that "even the dimmest law student can be counted upon to parrot the ritual phrases on command"); Arthur Linton Corbin, Taxation of Seats on the Stock Exchange, 31 Yale L.J. 429, 429 (1922) ("Our concept of property has shifted; ... . '[P]roperty' has ceased to describe any res, or object of sense, at all, and has become merely a bundle of legal relations-rights, powers, privileges, and immunities."); Edward L. Rubin, Due Process and the Administrative State, 72 Cal. L. Rev. 1044, 1086 (1984) ("[P]roperty is simply a label for whatever 'bundle of sticks' the individual has been granted."). Greg Alexander has traced the first known use of the metaphor to a late nineteenth-century treatise on eminent domain. See Gregory S. Alexander, Commodity \& Propriety: Competing Visions of Property in American Legal Thought, 1776-1970, at 323, 455 n.40 (citing John Lewis, A Treatise on the Law of Eminent Domain in the United States 43 (3d ed. 1909)).

${ }^{31}$ See Wesley Newcomb Hohfeld, Fundamental Legal Conceptions as Applied in Judicial Reasoning (Walter Wheeler Cook ed., 1919) (analyzing legal relations into four sets of jural opposites and correlatives and replacing in rem right with a composite of rights holding between pairs of individuals); Calabresi \& Melamed, supra note 2 , at 1116-18 (discussing criteria for selecting basic methods of protecting entitlements).
} 
broadcast spectrum to air rights over land as "tend[ing] to obscure the question that is being decided." "32 Instead, Coase thought about all resource allocation questions in terms not just of the realist bundle-of-rights picture of property, but, in some sense, not as property at all: "[W]hether we have the right to shoot over another man's land has been thought of as depending on who owns the airspace over the land. It would be simpler to discuss what we should be allowed to do with a gun." ${ }^{33}$ In Coase's viewand in most law and economics-legal rules are evaluated in terms of how well they can allocate a resource between two people who have announced incompatible uses. ${ }^{34}$

Property law proceeds very differently. Rather than being a list of use rights, property responds to uncertainty over uses by bundling uses together, often without needing to specify them at any stage. Property gives the right to exclude from a "thing," enforceable against everyone else-it is an in rem right-and a crude delegation to the owner avoids the costs of delineating use rights. On the dutyholder side, the message is a simple one-to "keep out"-and this simultaneously protects a reservoir of uses for the owner without officials or dutyholders needing to know what those might be. ${ }^{35}$ This is what I have called elsewhere an exclusion strategy, in which very rough signals or informational variables-such as presence inside or outside the boundary line around a parcel of land-are employed to protect an indefinite

\footnotetext{
${ }^{32}$ R.H. Coase, The Federal Communications Commission, 2 J.L. \& Econ. 1, 34 (1959).

${ }^{33}$ Id. (emphasis added). For a discussion of this hyperrealist aspect of Coase's assumptions about property, see Merrill \& Smith, What Happened to Property in Law and Economics?, supra note 3, at 366-75.

${ }^{34}$ See Coase, supra note 1 , at $15-28$. For a discussion of how Coase presupposes that property can be treated as the list of use rights that emerges from decisions of the type $A$ v. $B$ and how this approach is carried forward in the literature on property rules and liability rules, see Merrill \& Smith, What Happened to Property in Law and Economics?, supra note 3, at 369-71, 379-83.

${ }^{35}$ Many theorists have noted the tight connection between the right to exclude and property. See supra note 21. Building on the work of Steven Cheung, Carol Rose develops a typology of pollution controls and uses the term "keep out" as a shorthand for simple rules of exclusion. Steven N.S. Cheung, The Structure of a Contract and the Theory of a Non-Exclusive Resource, 13 J.L. \& Econ. 49, 64 (1970); Carol M. Rose, Rethinking Environmental Controls: Management Strategies for Common Resources, 1991 Duke L.J. 1, 9-36 [hereinafter Rose, Rethinking Environmental Controls].
} 
class of uses with minimal precision. ${ }^{36}$ The right to exclude is built around a signal-presence inside or outside a boundary-that is not directly tied to use but that when invoked protects the owner's interest in use indirectly. If $A$ owns Blackacre in fee simple, $A$ can vindicate her interest in using Blackacre for growing crops, living on it, running a parking lot, or engaging in any of an indefinite set of other uses by exercising her right to exclude others from Blackacre. ${ }^{37}$ By contrast, what I call a governance strategy is one in which the internalization problem is addressed on something close to a use-by-use basis; rights are delineated using signals (sometimes termed "proxies" or "proxy variables" in the economic literature) that pick out and protect individual uses and user behavior. ${ }^{38} \mathrm{Be}$ tween these two extremes are strategies of a mixed sort that bunch uses together under signals of intermediate precision. Easements are a prime example in that an easement gives a hard-edged, in rem right to exclude, but from a narrow and sometimes highly detailed set of uses. ${ }^{39}$ For example, we move further from exclusion to governance when a railroad easement might give the easement-

\footnotetext{
${ }^{36}$ See Smith, Exclusion versus Governance, supra note 3, at S454-56, S467-78.

${ }^{37}$ Not all such uses may be permitted where this basic exclusionary regime is supplemented by governance regimes such as zoning and other land-use regulations.

${ }^{38}$ See Smith, Exclusion versus Governance, supra note 3, at S455, S468-78.

${ }^{39}$ See id. at S455 (citing Preseault v. United States, 100 F.3d 1525 (Fed. Cir. 1996) (determining nature of railroad grant as easement rather than fee simple)). The question of the scope of an easement often involves a court in detailed consideration of the nature of a use. See, e.g., Beloit Foundry Co. v. Ryan, 192 N.E.2d 384, 390 (Ill. 1963) ("However, an easement appurtenant may not be extended by the owner of a dominant estate to accommodate other lands which he may own and for which the easement was not originally intended."); Hayes v. Aquia Marina, Inc., 414 S.E.2d 820, 823 (Va. 1992) (affirming trial court's finding that expansion of an easement holder's narina did not impose an additional and unreasonable burden and that paving of a roadway was a reasonable improvement of the easement); Brown v. Voss, 715 P.2d 514, 518 (Wash. 1986) (rejecting traditional approach and upholding trial court's refusal of injunction and award of damages based on balancing factors in case where plaintiff used easement for ingress and egress to a parcel and to an additional parcel on the other side from the servient parcel); Restatement of Property $\S 478(\mathrm{e})$ (1944) (proposing a flat rule of misuse if the purpose of one traversing servient land is to go to a nondominant parcel). Under one approach, what uses are permissible may turn not on whether they expand the easement but whether they can be presumed to have been contemplated by the parties in light of the purpose of the grant. See Preseault, 100 F.3d at 1542 (citing 3 Powell on Real Property \$ 34.12[2] (Patrick J. Rohan ed., 1996)).
} 
holder a right to traverse a parcel for any purpose, only for running trains, or merely for a given volume of train traffic, and so forth.

The information-cost theory explains the preference for injunctive remedies and sanctions where core property is at stake. ${ }^{40}$ Property rules provide for such a strong remedy that, in theory, they would deter all takings of entitlements without the owner's consent. ${ }^{41}$ They include injunctions and supracompensatory damages that would make a nonconsensual taking of an entitlement less attractive than bargaining to a consensual price with the present owner. By contrast, liability rules rely on officially determined nonmarket "prices," and allow others to take the owner's entitlement as long as these officially determined damages are paid. ${ }^{42}$ Situations are quite common in which a rough but low-cost and stable exclusion-type signal can capture many uses and delegate choices among uses to owners, and property rules are suited to reinforce this delegation to owners by forcing anyone who wants to engage in a use to bargain with the present owner. Liability rules tend to be associated with governance rules, which are used to fine-tune basic exclusionary regimes in high-stakes contexts. ${ }^{43}$ Interestingly, this theory allows us to explain why liability rules feature prominently in the literature even though they are less common than property rules in the law. Legal analysis tends to focus on borderline and high-stakes cases, where we expect governance rules to be more favored than they are overall. And because liability rules are associated more with governance than with exclusion, liability rules will get a great deal of attention from commentators with their focus on governance.

Where economists do acknowledge that exclusion and governance can be used to internalize externalities, they are at pains to deny any essential difference between them. In his thorough exploration of the notion of externality, for example, Andreas Papandreou argues that in fact there is no such distinction, that exclusion

\footnotetext{
${ }^{40}$ See Smith, Property and Property Rules, supra note 24 (arguing that informationcost theory explains the law's preference for property rules over liability rules despite the attractiveness of liability rules in most commentary).

${ }^{41}$ For the original formulation, see Calabresi \& Melamed, supra note 2, at 1092.

${ }^{42}$ See id.

${ }^{43}$ See Smith, Property and Property Rules, supra note 24.
} 
is just another form of governance. ${ }^{44}$ Conversely, governance rules can be said to "exclude" agents, but in terms of activities, and all entitlements are likely to be characterized by "exclusion" in this broad sense. ${ }^{45}$ Under this view, there is no essential difference between drawing and defending a boundary around an asset on the one hand and prescribing and enforcing norms about permissible activities with respect to the asset on the other.

I will argue that it does make sense to distinguish between methods of delineation based on how much they bunch uses together and that the benefits of delineating rights can be achieved at lower information costs when using particular combinations of strategies along the exclusion-governance spectrum. Under this view the terms "exclusion" and "governance" can be used to refer to the poles of this resultant spectrum, and these poles of exclusion and governance differ crucially in their cost structures. Exclusion is a low-cost, but low-precision, method that relies on rough informational variables like boundaries to define legal entitlements. Adding precision to rights using these variables starts out cheap but can quickly become prohibitively expensive. Capturing the impact on a resource of multiple uses-for example, the proper amount and timing of grazing by sheep - cannot easily be accomplished with better fences or better trained dogs. ${ }^{46}$ By contrast, rules prescribing proper use start out expensive. Imagine trying to delineate the legal relations holding between potential pairwise combination of citizens with respect to each thing by spelling out what each person-Coase's person shooting a gun, for example-can do to everyone else and who can sue when to stop what. At least as a rough

${ }^{44}$ Andreas A. Papandreou, Externality and Institutions 207-08 (1994).

${ }^{45}$ Id. at 208; see also Richard A. Posner, Economic Analysis of Law $\$ 3.1$, at 35 (4th ed. 1992) ("We could, of course, preserve exclusivity in a purely notional sense by regarding the property right in a given thing as a bundle of distinct rights, each exclusive; that is in fact the legal position."). Relatedly, having a right means having a claim that others not interfere with the exercise of the right, and having a liberty seems to be more than having a Hohfeldian privilege. See Judith Jarvis Thomson, The Realm of Rights 53 (1990). Defining exclusion as being able to invoke the law or social sanction to prevent an interference with any of a given set of activities makes exclusion so broad as to be characteristic of any right, not just property.

${ }^{46}$ See Robert C. Ellickson, Property in Land, 102 Yale L.J. 1315, 1329 (1993) [hereinafter Ellickson, Property in Land]. For a detailed case study of such restrictions, see, for example, Karen J. Friedmann, Fencing, Herding, and Tethering in Denmark, from Open-Field Agriculture to Enclosure, 58 Agric. Hist. 584, 593-94 (1984). 
first pass, it does make sense to talk of air rights and not what one can do with a gun (and all other conceivable activities). But as precision becomes more valued-perhaps because the gains from specialization through multiple use become more important-at some point governance may become more desirable than crude exclusion, at least from an information-cost perspective: The very multiple-use situations that fences and barking dogs cannot handle are fertile ground for rules of proper use-a governance regime.

Exclusion allows courts to avoid dividing rights into component use rights. Thus, exclusion carries with it information-cost savings even where transaction costs are high. Even where present transacting may not be cost-effective, exclusion can still make sense. The owner can select among uses (and "nonuse"), can contract with others for access now, or can contract later. For example, if the owner of Blackacre believes that its woods and rock formations will be a tourist attraction ten years from now, the owner can wait and see. Delegation through the gatekeeper right of exclusion allows the owner to make this decision without having to justify it to third parties, including courts and other officials. The owner can choose among uses and can act as a broker between the present and the future. ${ }^{48}$ The optimal transaction may not occur until well into the future. A judicial governance regime would allow another to take part or all of the entitlement by paying a non-market price determined by a court. Under this regime, a taker can force this substitute for a transaction to happen now, which may be far more expensive than a transaction in the future. Thus, even if present transaction costs are high, one should not automatically assume that private ordering is not working.

The exclusion strategy is low cost because it relies on crude signals that capture fewer of the benefits of specialized multiple use than higher cost governance rules can. Presence inside or outside a boundary around Blackcare is both overinclusive and underinclusive as a signal of harm to the land. It is overinclusive because not

\footnotetext{
${ }^{47}$ Rights falling towards the exclusionary end of the spectrum do not suffer from the "antiwilderness bias" that balancing courts may introduce into property law. See John G. Sprankling, The Antiwilderness Bias in American Property Law, 63 U. Chi. L. Rev. 519 (1996).

${ }^{48}$ Harold Demsetz, Toward a Theory of Property Rights, 57 Am. Econ. Rev. (Papers \& Proc.) 347, 355 (1967).
} 
all those present on the land would be causing harm, and it is underinclusive because one can cause harm to a person's interest in land without entering it, as by blocking access to it. Nevertheless, the roughness in exclusion is part and parcel of the delegation of the information-gathering function to owners. This delegation can seem extreme at first blush. In Jacque v. Steenberg Homes, Inc., the Wisconsin Supreme Court upheld a jury award of punitive damages of $\$ 100,000$ in a trespass case in which the jury had awarded nominal compensatory damages of only one dollar. ${ }^{49}$ The plaintiffs sued a mobile home company for traversing their land to deliver a mobile home to a neighboring tract. For the deliverymen, traversing the Jacques' tract would save a lot of time, trouble, and possible danger in navigating a sharp bend in the snow. ${ }^{50}$ The company representatives asked for permission and offered compensation, but the Jacques refused even in the face of an unofficial mediation by the town chairman. ${ }^{51}$ The court noted that the Jacques "were sensitive about allowing others on their land because they had lost property valued at over $\$ 10,000$ to other neighbors in an adverse possession action." 52 After all the back and forth, there could be no doubt that the company's entry was intentional; in addition, disputed testimony suggested that the exasperated foreman told the workers to cross the Jacques' land using epithets for emphasis. ${ }^{53} \mathrm{On}$ the face of it, a remedy of punitive damages might not seem to be in order because the Jacques seemed to be holding out for no good reason. ${ }^{54}$ But the court allowed punitive damages in order to vindicate the right to exclude and noted that without them, intentional violations of the right to exclude could not be deterred. ${ }^{55}$ In other words, the right to exclude was protected by a property rule, with no inquiry into owner reasonableness or the benefits of the defen-

\footnotetext{
${ }^{49} 563$ N.W.2d 154 (Wis. 1997).

${ }^{\text {so }}$ Id. at 157.

${ }^{51}$ Id.

${ }^{52}$ Id. Their belief was mistaken because permission negates the hostility required for adverse possession or prescription.

${ }^{53}$ Id.

${ }^{54}$ A claim of adverse possession or prescription must be hostile; the claimaint must possess or use the property without the owner's permission. See 3 American Law of Property $\$ 15.4$ (A. James Casner ed., 1954); William B. Stoebuck \& Dale A. Whitman, The Law of Property $\S 8.7$, at $453-55$, $\$ 11.7$, at 856-57 (3d ed. 2000).

${ }^{55}$ Jacques, 563 N.W.2d at $158-62$.
} 
dants' actions. I will argue that this strong form of delegation of the "gatekeeper" right to owners-even in the face of facts like those of Jacque-makes sense on an information-cost theory: Judges and juries need not individuate and evaluate the reasonableness or value of uses of the land.

Delegating the information-gathering function through the exclusion strategy lowers information costs. First and most basically, it frees actors, including courts, from having to develop first-order information about things. The information-cost savings go beyond avoiding the familiar problems of estimating damages. Courts need only deal with second-order information about the delegation itself. They do not even need to differentiate, much less evaluate, individual potential uses. This avoidance of information gathering by courts allows owners to undertake the choice among uses without having to justify the decision to third parties, unless the owner chooses to transact with another. Thus, the owner of Blackacre who believes that the land will be a tourist site in the future can act on a hunch, and property protection allows the owner to bear the consequences of this bet on the future without needing to articulate it to others. Owners can deal with these use choices at an intuitive level because for most purposes they are not subject to review.

Further, the delegation achieved under the exclusion regime sends a simple message to dutyholders-to keep off-and this has value where many nonexpert third parties must heed the warning. This third-party information-cost advantage is relevant to private transactors who want to determine the rights they can acquire through transactions, but it is also valuable for those who simply need to respect rights in order to avoid liability for violating them. And because the rules of exclusion are simple, it is easy to announce them ex ante. At the cost of some roughness and error from lack of tailoring, ex ante certainty and stability is possible under the exclusion regime. For this reason, I will argue that the results in trespass and the exclusionary physical invasion part of nuisance law are far more predictable than is the balancing of utilities approach that has been gaining favor, especially among commentators. And, again, the delegation to owners through exclusion allows courts to avoid evaluation of uses in the first place. Nuisance is itself more exclusionary than is conventionally thought, and this quality reflects the benefits of delegation to owners. 
Because the "things" that are the subject of property law are heterogeneous collections of valued attributes, the delegation through exclusion also avoids an opportunism problem. ${ }^{56}$ Given positive information costs, there is good reason to think that using the exclusion strategy often yields a better result than would combining governance rules and devices to minimize strategic behavior. Under governance rules, a court has to weigh the value of various uses, the ones announced by the owner and the conflicting one of the taker-the polluter in the classic nuisance example. This balancing becomes even more informationally demanding where the governance rule is implemented with a liability rule-a judicial price for a use right. Where courts have limited abilities to identify and evaluate the competing information about uses presented by parties to a nuisance dispute, potential takers can engage in strategic behavior that defeats the owner's investment in the asset.

Exclusion and property rules provide robust protection for owners. Owners are closest to their assets and will be in a position both to develop information about (and attachment to) their assets and will be the recipients of information in the form of offers from potential purchasers. ${ }^{57}$ Owners are likely often to be the least-cost generators of information about assets, even if this information is not verifiable to third parties. Takers will likely be closer to assets than courts, and will be able to evaluate assets currently held by owners. Under exclusion and property rule protection, people in this position have to make offers, but under liability rules, which are often used in a governance regime, takers can use information about assets and their owners to cherry-pick those undervalued by damages rules. ${ }^{58}$ An owner may not be able to communicate to a

\footnotetext{
${ }^{56}$ For a more detailed version of the following opportunism argument in the context of the property rule-liability rule debate, see Smith, Property and Property Rules, supra note 24 , at $34-46$.

${ }^{57}$ That owners are in a particularly good position to maximize the value of resources they own is a common assumption among traditional property theorists, see Merrill \& Smith, What Happened to Property in Law and Economics?, supra note 3, at 360-66 (discussing and quoting expressions of concern for investment among traditional theorists), and in much of the liability rule literature, see, for example, Ian Ayres \& Eric Talley, Solomonic Bargaining: Dividing a Legal Entitlement to Facilitate Coasean Trade, 104 Yale L.J. 1027, 1083-86 (1995) (discussing investment incentives for owners); Kaplow \& Shavell, supra note 2, at 768-69 (arguing for systematic protection of owners over takers on grounds that owners are creators of value).

${ }^{58}$ Smith, Property and Property Rules, supra note 24.
} 
court the value of a use (or nonuse) such that damages could be given to reflect it. Takers, knowing this, can then select vulnerable owners for taking or extortion..$^{9}$ Even if a court could detect all opportunistic takings, the effort to do so is likely to be costly. ${ }^{60} \mathrm{Ex}$ clusion allows courts to avoid evaluating or even inquiring into the identity of uses of property. ${ }^{61}$

A court will be faced with an owner claiming a high value and a taker claiming a lower one. If a court engages in use-by-use entitlement determination, then one of three problematic results could obtain. First, under property rules or liability rules one stick in the bundle of use rights is hived off and given to the party who can convince the court that its use is more valuable. Speculative uses discovered by entrepreneurs (and idiosyncratic value to ordinary owners) will be the least credible uses and will systematically find too little favor. Second, courts could automatically accept claims of self-styled entrepreneurs, but then such people will be wastefully overcompensated (and will invest in fake projects in another form of strategic behavior). Finally, a court could try to develop information about the speculative use independently, but it is likely to be a higher cost producer and user of such information than the entrepreneurial owner, almost by definition. Even if the court correctly guesses that the current owner has discovered the higher use but finds that the taker is in a better position to use the asset as a tourist site, it would be very easy for the court to over- or undercompensate the existing owner for developing the information about the use as a tourist site.

Basic reliance on exclusion and property rules and reserving governance and liability rules for supplementary fine-tuning can reduce problems of opportunism. Problems for liability rules arise

\footnotetext{
${ }^{59}$ See id. at $47-49$ (showing that a wide range of liability rules can lead to opportunism); David D. Haddock \& Fred S. McChesney, Do Liability Rules Deter Takings?, in The Economic Consequences of Liability Rules: In Defense of Common Law Liability 29, 38-39 (Roger E. Meiners \& Bruce Yandle eds., 1991) (showing that market damages will invite opportunistic takings and attendant waste); see also Kaplow \& Shavell, supra note 2, at 765-77 (arguing that nonbiased average damages can lead takers to be attracted to things that are undervalued by the liability rule).

${ }^{60}$ For an argument that courts stepping in with liability rules to solve bargaining problems will lead parties to bargain less cooperatively and lower transaction costs on their own, see Krier \& Schwab, supra note 2, at 464. 24.

${ }^{61}$ For a more detailed analysis, see Smith, Property and Property Rules, supra note
} 
where takers or owners can anticipate the proxy variables that a court will use to determine value and alter their behavior in order to exploit the proxy's inaccuracies. As an (oversimplified) example, if a court measured value by referring to market transactions over nearby parcels, a taker might single out an owner whose parcel is more valuable than it would appear in light of market transactions over "comparable" parcels. These problems even extend to a situation where a polluter is seeking to extort from an owner part of the value of a parcel-for example, the value of a future tourist site. ${ }^{62}$ Conventional analysis of liability rules assumes that the conflict has been framed in terms of identifiable uses, about which probabilistic information about values is readily obtainable. Simply saying, as law-and-economics commentators do, ${ }^{63}$ that all courts need to do is get such situations right on average is not persuasive where owners and takers are better than courts at developing information about multi-dimensional assets in the presence of uncertainty. In property disputes, however, the difficulty often is that of identifying the relevant uses of a multi-attribute asset and placing each asset and use in its appropriate actuarial class to begin with.

One type of evidence supporting this information-cost theory about delineating rights is that exclusion does seem to be the more basic and foundational strategy in a wide variety of property situations. In common pool resources, commoners first exclude outsiders and then institute rules of proper use among themselves. ${ }^{64}$ The

\footnotetext{
${ }^{62}$ Kaplow and Shavell discuss the situation in which an owner and takers place a common value in excess of "average" damages, which will lead to a problem of multiple takings. See Kaplow \& Shavell, supra note 2, at 765-77. But see Ian Ayres \& Paul M. Goldbart, Correlated Values in the Theory of Property and Liability Rules, $32 \mathrm{~J}$. Legal Stud. 121 (2003) [hereinafter Ayres \& Goldbart, Correlated Values] (arguing that sophisticated liability rules can solve the correlated value problem). They further believe that this problem arises primarily in the case of takings of things and not with externalities. Kaplow \& Shavell, supra, at 771-73. If, however, the basic problem is opportunism in response to inadequate actuarial classes, problems can arise even in the absence of many takers and even in the case of externalities. See Smith, Property and Property Rules, supra note 24.

${ }^{63}$ See, e.g., Kaplow \& Shavell, supra note 2, at 719, 765-77 (arguing for superiority of liability rules based on "the average harm for cases characterized by the facts the court observes" but arguing for property rule protection in the case of tangible things even if courts can get damages right on average).

${ }^{64}$ See, e.g., James M. Acheson, The Lobster Fiefs Revisited: Economic and Ecological Effects of Territoriality in the Maine Lobster Industry, in The Question of the Commons 41, 61-63 (Bonnie J. McCay \& James M. Acheson eds., 1990); James M.
} 
simple message to keep out is all that is needed in order for most people to bring out the value of the resource, and more detailed use rules can then be directed to those with high stakes and good information about it. Robert Ellickson hypothesizes that institutions developed among close-knit groups will be wealthmaximizing for the members of the group, but not necessarily efficient in any wider sense. ${ }^{65}$ Consider this in connection with closeknit groups' efforts at exclusion, which come in two broad typesexclusion of nongroup members and exclusion of group members by owners within the group. As for the former, one might think that groups excluding nonmembers are doing no more than grabbing resources, but it does seem that the ability to exclude outsiders often promotes conservation and sustainability of commonpool resources. ${ }^{66}$.

We have even more reason to think that institutions are efficient when their costs and benefits are more internalized to the members of the group; importantly, close-knit communities not only exclude outsiders but they often institute rights to exclude among themselves. The rise of family beaver-hunting territories among the $\mathrm{Na}$ tive Americans of the Labrador peninsula is a famous example, ${ }^{67}$

Acheson, Variations in Traditional Inshore Fishing Rights in Maine Lobstering Communities, in North Atlantic Maritime Cultures: Anthropological Essays on Changing Adaptations 253, 262 (Raoul Andersen ed., 1979) (arguing that there would be little point in the lobster gangs' maintaining strict norms of proper use without limiting their membership); Carol M. Rose, The Several Futures of Property: Of Cyberspace and Folk Tales, Emission Trades and Ecosystems, 83 Minn. L. Rev. 129, 144, 155 (1998) (pointing out that common-property regimes may look like a commons on the inside but act like property on the outside); Smith, Exclusion versus Governance, supra note 3, at S482-83.

${ }^{65}$ See Robert C. Ellickson, Order without Law: How Neighbors Settle Disputes 169 (1991) [hereinafter Ellickson, Order without Law]; Ellickson, Property in Land, supra note 46 , at 1400 .

${ }^{66}$ See, e.g., James M. Acheson, The Lobster Gangs of Maine 55-58 (1988) (discussing the superiority of lobster stocks in areas with more exclusive territories); Elinor Ostrom, Governing the Commons: The Evolution of Institutions for Collective Action 90 (1990) (listing "clearly defined boundaries" as a design principle illustrated by long-enduring common pool resource ("CPR") institutions, where "[i]ndividuals or households who have rights to withdraw resource units from the CPR must be clearly defined, as must the boundaries of the CPR itself").

${ }^{67}$ Demsetz, supra note 48, at 351-53; Ellickson, Property in Land, supra note 46, at 1320-21. Demsetz used the example of the rise of family beaver-hunting territories among the Native Americans of the Labrador peninsula as an example of property rights that emerged when the fur trade caused the gains from defining territories to 
but far from unique among aboriginal societies ${ }^{68}$ and other closeknit groups. ${ }^{69}$ In our terms, such societies employ a mix of exclusion and governance. In such systems, we sometimes find exclusion operating alone (especially with respect to outsiders), but it is unusual to find governance rules over a resource with no exclusion whatsoever, which is consistent with an exclusion regime as being the "first cut" in terms of information costs. ${ }^{70}$ Further, as the pressure on and value of resources rise, we often find a shift from exclusion to governance of a resource. ${ }^{71}$ These patterns suggest that exclusion is more basic and that governance serves a supplemental finetuning function, as information-cost theory would predict.

As the common pool situations remind us, these governance rules can come from judges, as in nuisance, or they can emerge from either private contracting, the development of informal norms, or the activities of regulatory authorities. These different institutional suppliers of use rules have their own advantages and weaknesses, but what they have in common is an ability to achieve

exceed the costs. The questions of whether the family hunting territories among any of the Northern Algonquin tribes antedated the fur trade and whether the strength of territories correlates with the length of the fur trade or the lack of importance to a tribe of big game have been debated for almost a century and are still hotly contested. See, e.g., John C. McManus, An Economic Analysis of Indian Behavior in the North American Fur Trade, 32 J. Econ. Hist. 36, 39 n.10 (1972); see also William Cronon, Changes in the Land: 1ndian, Colonists, and the Ecology of New England 104, 194 n.40 (1983) (noting and citing contributions to the debate over Algonquian family hunting territories and taking a moderate position for some precolonial parcelization that became more fixed in the trading era).

${ }^{68}$ Martin J. Bailey, Approximate Optimality of Aboriginal Property Rights, 35 J.L. \& Econ. 183, 183 (1992) (finding widespread use of exclusive rights among more than fifty aboriginal groups).

${ }_{69}$ Smith, Exclusion versus Governance, supra note 3, at S484-85; Henry E. Smith, Semicommon Property Rights and Scattering in the Open Fields, 29 J. Legal Stud. $131,144-54,161-67$ (2000). Ellickson surveyed societies that can be termed close-knit and found widespread private rights. Some of these-such as rights to crops and hunting territories-fall towards the exclusion end of the spectrum, while others-such as usufructs and rights to withdraw flows-fall further towards the governance end. Ellickson, Property in Land, supra note 46, at 1331-32, 1367-68.

${ }^{70}$ Smith, Exclusion versus Governance, supra note 3, at S485-86.

${ }^{71}$ See id. at S486 (noting that "[a]s resource values increase, we can get either more governance or more fine grained exclusion"); Rose, Rethinking Environmental Controls, supra note 35, at 8-24 (arguing that as pressure on a given resource increases, the optimal commons management strategy shifts from simple exclusion to more complex regulatory strategies). 
high levels of precision more efficiently than can pure strategies of exclusion.

\section{LOCATION IN THE LAW OF TRESPASS AND NUISANCE}

In the context of land, the right to exclude is implemented largely through the law of trespass and nuisance. ${ }^{72}$ Roughly speaking, trespass is concerned with invasions that interfere with "possession," and possession, generally speaking, is a right to control not identical with full ownership. ${ }^{73}$ Possession, in turn, tends to use very simple signals that are aimed at a large and indefinite (in rem) audience of those who have to "keep off.".74 The law of private nuisance presents a more complicated picture than trespass, because at times nuisance law is highly exclusionary and resembles trespass, but at other times nuisance is concerned with balancing the costs

${ }^{72}$ The law of personal property vindicates the right to exclude through trespass to chattels. Trespass to chattels is similar to trespass to land in conditioning liability on obvious interferences with the chattel but does not allow for nominal damages in the absence of provable harm. See Restatement (Second) of Torts $\$ 217 \mathrm{cmt}$. e (1965). On how the right to exclude operates in the context of intangible rights like intellectual property, see, for example, Henry E. Smith, Intellectual Property as Property: An Information-Cost Approach (draft on file with author and the Virginia Law Review Association) (analyzing right to exclude from uses of information as relying on relatively low cost but rough signals); see also Penner, The Idea of Property, supra note 21, at 50,111-27 (discussing the thesis that the thinghood of objects of property stems from their separability from the current holder).

${ }^{73}$ A leading case on possession is Pierson v. Post, 3 Cai. R. 175, 179 (N.Y. Sup. Ct. 1805) (considering whether pursuit of a wild animal constitutes possession), and a recent, famous example is Popov v. Hayashi, No. 400545, 2002 WL 31833731 (Cal. Super. Ct. Dec. 18, 2002) (analyzing the disputed possession of the infamous Barry Bonds home run ball). See also, F.H. Lawson, Introduction to the Law of Property 33 (1958) ("In practice indeed possession is often said to be a social rather than a physical fact, in the sense that a person will be held to possess a thing if he has the sort and extent of control that society, considered as being represented by the ordinary reasonable man, would regard as appropriate to the kind of thing and the circumstances of the case."); Carol M. Rose, Possession as the Origin of Property, 52 U. Chi. L. Rev. 73, 73 (1985) (addressing the puzzle of how things come to bc owned) [hereinafter Rose, Possession]; Henry E. Smith, The Language of Property: Form, Context, and Audience, 55 Stan. L. Rev. 1105, 1115-25 (2003) [hereinafter Smith, Language of Property] (demonstrating that, in the law of possession, courts seek clear rules that reduce complexity). In a bailment, for example, possession without ownership is transferred to the bailee.

${ }^{74}$ Smith, Language of Property, supra note 73, at 1115-25. 
and benefits of uses and exhibits the hallmarks of a judicial governance regime. $^{75}$

Being able to explain the hybrid nature of nuisance law in information-cost terms will help resolve a longstanding puzzle. Commentators who recognize the hard-edged character of traditional nuisance law have justified this aspect in corrective justice terms and have conceded that it conflicts both with economic analysis and other utilitarian approaches. ${ }^{76}$ For example, early in his career Richard Epstein favored strict liability and a heavy reliance on physical invasion tests in nuisance, subject to softening by utilitarian constraints such as "live and let live" that come in as defenses only. ${ }^{7}$ More recently he has resolved the conflict in more Coasean and utilitarian balancing terms, but still sees the conflict between exclusion and tailoring as one between pure and less pure corrective justice approaches. ${ }^{78}$ The information-cost theory, however, suggests that (what I call) exclusion versus governance does not line up so neatly with corrective justice versus utilitarianism. I do not claim that the information-cost reasons for exclusion constitute the entire rationale for that type of rule and, as mentioned earlier, an information-cost theory extends many of the traditional rationales for property based on investment and stability in a way that allows them to withstand the apparent Coasean logic of the conventional law and economics of nuisance. But I will argue that there are information-cost specific reasons to favor exclusion in the law of nuisance that cause the two major approaches, corrective

${ }^{75}$ In this Article, I focus on private nuisance. Public nuisance partakes more of public regulation, and as expected on the information-cost approach, is even more governance-like than the law of private nuisance.

${ }^{76}$ See, e.g., Epstein, Nuisance Law, supra note 14, at 74-75; see also Penner, Nuisance and the Character of the Neighbourhood, supra note 12, at 14-25 (arguing that nuisance law in its traditional tort context of rights is more effective than a regime of nuisance law that hinges upon economic analysis).

${ }^{77}$ Epstein, Nuisance Law, supra note 14, at 60-75, 82-87.

${ }^{78}$ See, e.g., Richard A. Epstein, A Conceptual Approach to Zoning: What's Wrong with Euclid, 5 N.Y.U. Envtl. L.J. 277, 282 (1996) ("[Nuisance] law does not work on a moral or deductive principle. Rather, it works on a rough empirical generalization that will be false in some cases but true in most: we should permit only those activities in which the benefits to the land owner exceed the costs from dirt and filth to the neighbor."); Richard A. Epstein, Holdouts, Externalities, and the Single Owner: One More Salute to Ronald Coase, 36 J.L. \& Econ. 553 (1993) [herienafter Epstein, Holdouts] (adopting Coasean analysis in contrast to earlier views and advocating a "single owner" principle for resolving use conflicts). 
justice and utilitarianism, to coincide here more than their adherents would have admitted.

\section{A. Trespass versus Nuisance}

Trespass and nuisance both protect landowners' interests in the use of their land, but they do so in very different ways. The law of trespass applies to gross physical invasions by visible objects, applies a test of strict liability, and routinely allows for injunctions. ${ }^{79}$ In our terms, trespass is an exclusion regime because it simply asks whether the defendant caused some physical object to enter the column of space defined by the ad coelum rule..$^{80}$ The informational variables used relate to causation and location, leading to a standard for liability that is "exceptionally simple and exceptionally rigorous." direct intrusions such as noise, odor, and occasionally aesthetic blight, that interfere with an owner's use and enjoyment of her land; nuisance is sonietimes based on a balancing of the benefits and harms from the offending activity, and may more readily employ a remedy of damages than in trespass. ${ }^{82}$ Under more modern approaches to nuisance, balancing tests are often invoked at the liability or remedy stage, although evidence of courts actually engaging in cost-benefit analysis is surprisingly slight. ${ }^{83}$ In the law of pri-

\footnotetext{
${ }^{79}$ See W. Page Keeton et al., Prosser and Keeton on the Law of Torts, $\$ 87$, at 622 (5th ed. 1984) [hereinafter Prosser and Keeton on Torts]; Merrill, supra note 13, at 14-20.

${ }^{80}$ The full statement of the maxim is cujus est solum, ejus est usque ad coelum et ad inferos (he who owns the soil owns also to the sky and to the depths). The maxim is routinely followed in resolving issues about ownership of air rights, building encroachments, overhanging tree limbs, mineral rights, and so forth, and is subject to certain limited exceptions for activities like airplane overflights. See Brown v. United States, 73 F.3d 1100, 1103-04 (Fed. Cir. 1996); Merrill, supra note 13, at 26-35.

${ }^{81}$ Prosser, supra note 17, at 63 (quoting 1 Thomas Atkins Street, Foundations of Legal Liability 19 (1906)).

${ }^{82}$ Prosser and Keeton on Torts, supra note 79, $\$ \S 86-91$.

${ }^{83}$ William L. Prosser, Handbook of the Law of Torts $\$ 89$, at $596-602$ (4th ed. 1971) (considering the "reasonable use" balancing test and citing modern case applications). Under the Second Restatement, a nuisance is a substantial nontrespassory invasion of use and enjoyment of land that is caused either by intentional and unreasonable activities, or negligent, reckless, or ultrahazardous activities. $\mathrm{Re}$ statement (Second) of Torts $\S \S 821 F, 822$ (1979). Intentional nuisances largely turn on reasonableness:
} 
vate nuisance, injunctions are awarded for more serious nuisances and where damages would be inadequate. I will argue that nuisance partakes both of an exclusionary and governance-like aspect; for the more serious and clear cases of nuisance, simple informational variables based on border crossing are employed, but the law of nuisance supplements the exclusionary foundation with rules on proper use, subjecting conflicting uses to various types of balancing and reasonableness analyses.

The tests for classifying harms as trespass or nuisance reflect a greater reliance on exclusion in trespass. At various times, four tests, each of which is at least occasionally invoked, serve to demarcate the boundary between trespass and nuisance. ${ }^{84}$ First, trespass may apply where there is a personal entry by the defendant. ${ }^{85}$ Second, trespass may be reserved for "direct" injuries to land as opposed to more indirect ones. ${ }^{86}$ Third, trespass may turn on

An intentional invasion of another's interest in the use and enjoyment of land is unreasonable if

(a) the gravity of the harm outweighs the utility of the actor's conduct, or

(b) the harm caused by the conduct is serious and the financial burden of compensating for this and similar harm to others would not make the continuation of the conduct not feasible.

Id. $\S 826$; see also id. $\S 827$ (setting out factors relating to gravity of the harm, including the social value of the plaintiff's use); id. $\$ 828$ (setting out factors relating to the utility of actor's conduct, including its social value); $6 \mathrm{~A}$ American Law of Property $\$ 28.22$, at 66, $\$ 28.26$, at 75-77 (A. James Casner ed., 1954) (emphasizing the vagaries associated with, and importance of, a determination as to whether a defendant's conduct is unreasonable); 1 Fowler V. Harper \& Fleming James, Jr., The Law of Torts $\$ 1.24$, at 70-74 (1956) (discussing the importance of reasonableness consideration in nuisance cases). See generally Jeff L. Lewin, Boomer and the American Law of Nuisance, 54 Alb. L. Rev. 189, 212-14 (documenting the limited adoption of the balance of the utilities test for reasonableness, and citing cases). Some courts invoking the Restatement formulations do not actually engage in the cost-benefit test and appear to be hewing to a more traditional approach to nuisance. See, e.g., Morgan v. High Penn Oil Co., 77 S.E.2d 682 (N.C. 1953).

${ }^{84}$ Merrill, supra note 13 , at 26-35.

${ }^{85}$ Id. at 27 . This is the oldest test.

${ }^{86}$ Id. at 27-28. This distinction traces back to the actions of trespass and case, the latter of which was for indirect injuries. Under a very traditional view, then, an overhanging part of a building would be the subject of a nuisance action rather than trespass because the building does not directly touch the plaintiff's land. See, e.g., Kafka v. Bozio, 218 P. 753, 755 (Cal. 1923) ("The wrong here complained of was an encroachment, not upon plaintiffs' land, but upon the space above the land, and therefore was not a trespass but a nuisance."). Now such a condition would be considered trespass. See, e.g., Puroto v. Chieppa, 62 A. 664, 665 (Conn. 1905) (holding that the 
whether individualized invading objects are visible to the naked eye, as are shotgun pellets, rocks, and people (but not smoke, odors, or aesthetic blight, which would fall under nuisance, if they are actionable at all) ${ }^{87}$ Fourth, trespass may be reserved for situations of substantial harm that constructively deny possession to the plaintiff. ${ }^{88}$

Previous commentary has identified a number of reasons for tailoring nuisance more precisely than trespass. Thomas Merrill has argued that the tests for distinguishing trespass and nuisance reflect courts' greater willingness to incur higher entitlement determination costs in those cases in which high transaction costs likely preclude a private bargain over the conflicting uses. ${ }^{89}$ Merrill argues that the first three tests all serve roughly to single out situations of low transaction costs for mechanical treatment by trespass. ${ }^{90}$ Who the invader is in a personal invasion is not difficult to discover. The notion of direct intrusions may be personal and may therefore involve only low transaction costs. The dimensional test, in particular, will tend to pick out situations in which the source of the particles is known and relatively close by, and the problem need not involve continuous monitoring. ${ }^{91}$ Merrill's analysis fits in well with what has been, until recently, the conventional wisdom in law and economics: that property rules are best in situations of low transac-

projection of flashboard by one inch over plaintiff's land constitutes a trespass entitling plaintiff to at least nominal damages); Cumberland Tel. \& Tel. Co. v. Barnes, 101 S.W. 301, 302 (Ky. 1907) (overhanging telephone pole arms a continuing trespass); Smith v. Smith. 110 Mass. 302, 304 (1872) (overhanging eaves are a trespass); Davies v. Bennison (1927) 22 T.L.R. 52 (Austl.) (shooting at cat on plaintiff's roof a trespass even though bullets never reached the ground); Prosser and Keeton on Torts, supra note $79, \S 13$, at 78-79 (discussing and citing cases involving overhanging objects and shooting over land); see also Butler v. Frontier Tel. Co., 79 N.E. 716, 718 (N.Y. 1906) (overhanging wires oust plaintiff from possession as required for ejectment action). See generally P.H. Winfield, Nuisance as a Tort, 4 Cambridge L.J. 189, 201-06 (1931) (discussing origins of the distinction between trespass and nuisance in the actions of trespass vi et armis and trespass upon the case).

${ }^{87}$ See Merrill, supra note 13, at 28-29 (citing cases).

${ }^{88}$ See, e.g., Martin v. Reynolds Metals Co., 342 P.2d 790, 798 (Or. 1959); Merrill, supra note 13, at 30 .

${ }^{89}$ Merrill, supra note 13. Some comınentators focus on the likelihood of bargains in light of the nature of the entitlement bargained over. See, e.g., Ayres \& Talley, supra note 57 (arguing that liability rules facilitate bargaining); Jason Scott Johnston, Bargaining Under Rules Versus Standards, 11 J.L. Econ. \& Org. 256, 259 (1995).

${ }^{90}$ Merrill, supra note 13 , at $31-34$.

${ }^{91}$ Id. at 33. 
tion costs and liability rules and tailoring are better for situations of high transaction costs because in such situations the court's word will be final. ${ }^{92}$ In a more normative vein, Richard Epstein argues that for reasons rooted in corrective justice, nuisance should be reconceived as being about physical invasions (in a manner very reminiscent of trespass). Epstein then identifies four utilitarian factors leading to relaxation of a strict corrective justice approach: high administrative costs, high transaction costs facing those reassigning rights voluntarily, low value of the rights that nuisance law qualifies, and presence of in-kind compensation that prevents systematic wealth transfers. ${ }^{93}$ In our terms, exclusion would correspond roughly to Epstein's corrective justice-inspired physical invasion approach.

Most of the special factors identified by Merrill and Epstein point away from exclusion, but one immediate question is when should high administrative costs lead us to expect simple rules of exclusion or a rule of no liability at all. Although high administrative costs can justify a failure to find liability-for de minimis harms-it can also be a reason to choose exclusion over governance. In trespass to real property, the classic exclusion regime, plaintiffs who cannot show substantial damage-or even who benefited from the trespass-can nonetheless recover nominal damages. ${ }^{94}$ Unlike in nuisance, there is no de minimis exception in trespass. ${ }^{95}$ One reason for the lack of a de minimis exception in trespass follows from its nature as an exclusion regime. Carving out the de minimis uses would forego the cost-savings of the simple informational variables of entry. A de minimis exception would also likely capture few benefits because gross physical invasions tend to be

${ }^{92}$ Calabresi \& Melamed, supra note 2, at 1106-10; see also, Robert Cooter \& Thomas Ulen, Law and Economics 104-07 (4th ed. 2004) (discussing the relationship between transaction costs and efficient remedies); Ayres \& Goldbart, Correlated Values, supra note 62, at 123 (noting the conventional wisdom and summarizing criticism); Daphna Lewinsohn-Zamir, The Choice between Property Rules and Liability Rules Revisited: Critical Observations from Behavioral Studies, 80 Tex. L. Rev. 219, 220 (2001) (discussing this traditional view and citing literature).

${ }^{93}$ Epstein, Nuisance Law, supra note 14, at 74-79, 82-90.

${ }^{94}$ Prosser and Keeton on Torts, supra note $79, \S 13$, at 75 .

${ }^{95}$ Id. Some courts have assimilated trespass law somewhat to nuisance and in effect allowed a de minimis exception for trespass, albeit probably more limited than that in nuisance. See, e.g., Borland v. Sanders Lead Co., 369 So. 2d 523, 529-30 (Ala. 1979); Martin v. Reynolds Metals Co., 342 P.2d 790, 795-96 (Or. 1959). 
easy for third parties to avoid. Indeed, part of the simplicity of the message to keep off, directed at the world at large, is that compliance is not likely to involve much effort or sacrifice in terms of time and effort-at least as compared to the wide and protean class of uses covered by the law of nuisance.

Likewise, at the opposite end of the intensity spectrum, information costs help explain the fourth test for trespass-substantial harm that leads to constructive dispossession-despite its not doing a particularly good job of identifying situations of low transaction costs (in the sense of bargaining costs). While it is true that the dividing line between substantial harm and other harms requires more judgment, once a situation fits under substantial harm, it requires little measurement. The idea is that some intrusions are so severe that they not only interfere with use and enjoyment but are a "constructive" interference with exclusive possession. In our terms, if an invasion is so severe that it interferes with all use, then it is likely that any hard-to-measure use is also being interfered with. If the invasion is not so severe, further measurement to determine whether the uses interfered with are being harmed is more likely to be worth the cost.

\section{B. Information Costs and the Nature of Nuisance Law}

The information-cost theory allows us to generalize and extend the factors favoring a more governance-type regime in nuisance law. Why would one want to move away from a system of delegation to owners of the function of gathering and acting on information about uses, towards a regime of off-the-rack governance rules? On the information-cost approach, the presence of high stakes ensures that some precision (towards the governance end of the spectrum) will be worthwhile. ${ }^{96}$ If, at the same time, the transaction costs of private contracting or the formation of informal norms are high, then judicial governance can be worthwhile.

As mentioned earlier, nuisance is a notoriously slippery area of the law, and I argue that it is all the more so because nuisance contains within itself a shift from the exclusion to the governance strategy. Recognizing this transitional aspect of nuisance will allow a better description of the apparent disorder in the case law and

\footnotetext{
${ }^{96}$ See Smith, Exclusion versus Governance, supra note 3, at S471-78.
} 
the even sharper divergence of views among commentators. In addition, the information-cost approach suggests the desirability of retaining exclusionary elements in nuisance law that have fallen somewhat out of favor.

As we have seen, trespass is more based on exclusion than is nuisance. Trespass protects against violations of rights of possession, which have highly exclusion-like aspects. The notion of possession is itself based heavily on low-cost, low-precision informational variables. Possession is a very crude proxy signal that does not involve detailed information, particularly of how the thing possessed is being used. ${ }^{97}$ Instead, the law of possession is designed to declare a clear owner in terms understandable by the world at large. ${ }^{98}$ Possession forms the rough beginning upon which further refinements in property law are built. By contrast, nuisance protects rights to the quiet use and enjoyment of land. Sometimes this involves an evaluation of particular uses, but a generalized concern with use can veer into exclusion. When a nuisance is significant or obvious, it can be regarded as interfering with any imaginable use. If so, then detailed inquiry into use is not necessary and an approach based on a general right to exclude emerges to vindicate the right to quiet use and enjoyment, without needing to specify exactly what use is involved or what its value might be.

\section{Substantial Harm}

The tendency of nuisance toward exclusion in cases of substantial harm makes sense in terms of the informational costs and benefits of isolating and evaluating uses. In situations of harm so great as to preclude multiple uses, there is no point in courts or others incurring the costs of precision, and here the law employs trespass

\footnotetext{
${ }^{97}$ Epstein, Possession, supra note 28, at 1222-23 (arguing that because of courts' modest remedial powers their "definition of rights is therefore apt to be made along certain 'natural lines'; there will be broad general propositions that can apply to all against all, and there will be no reference to the numbers or formulas ... that can be generated by direct administrative controls, such as zoning").

${ }^{98}$ Rose, Possession, supra note 73 , at 88 (noting that the standards for determining possession are based on "a specific vocabulary within a structure of symbols approved and understood by a commercial people"); Smith, Language of Property, supra note 73 , at $1115-25$.
} 
and trespass-like nuisance rules. ${ }^{99}$ The exclusion strategy can be found within the law of nuisance itself.

The doctrine of nuisance per se reinforces the exclusionary aspect of nuisance law. A nuisance per se is an activity that is so harmful that contextual information about the locality or the plaintiff is very unlikely to change the result. ${ }^{100}$ Nuisances that count as nuisances per se are not necessarily characterized by low transaction costs, but the information-cost theory gives reasons other than low transaction costs for favoring exclusion: In cases of nuisance per se, the benefit of further precision in court efforts at delineation seems small. Consequently, the doctrine of nuisance per se allows a conclusion of nuisance (and an injunction) without governance-like inquiry into the contextual details of a use-conflict.

\section{Location}

In a physical context such as land-use conflict, exclusion is typically implemented using locational variables-for example, has the defendant entered into the column of space around the resource? Though there is a tendency to think of nuisance as being about balancing the worth of activities, the most striking aspect of nuisance disputes is how much location matters. Despite the best efforts of Coasean thinkers to argue that causation is reciprocal and to discredit traditional, ordinary notions of one-way causation, the law still takes the notion of "invasion" by a tortfeasor of a victim's rights surprisingly literally. Thus, if trespass looks for physical invasions, especially by visible objects, nuisance is about invasions of a more ethereal sort. But the disturbance should emanate from the defendant's land and cause harm on that of the plaintiff.

As I will argue, despite the growing utility-balancing approach to the law of private nuisance, this branch of the law rests on an ex-

\footnotetext{
${ }^{99}$ Recall that trespass is a rule of strict liability. Keith Hylton uses a missing markets theory to predict that in situations where external costs are clearly greater than external benefits and transaction costs are high, the law tends towards strict liability. Keith N. Hylton, A Missing Markets Theory of Tort Law, 90 Nw. U. L. Rev. 977, 989-93 (1996).

${ }^{100}$ A nuisance per se is activity that constitutes a nuisance wherever and whenever it occurs. A nuisance per accidens is otherwise permissible activity that constitutes a nuisance only because of where or when it takes place. See, e.g., Morgan v. High Penn Oil Co., 77 S.E.2d 682, 687 (N.C. 1953).
} 
clusionary foundation supplemented by governance rules. Further, institutions other than courts, ranging from private parties in common interest communities to legislatures and administrative bodies, are probably better suited than courts to achieve the benefits of the regulation of harms like aesthetic blight. Traditionally, and to commentators' disappointment today, location and physical invasion are very important informational variables in the law of nuisance.

Consistent with the view that location is important is the relative ease with which courts have recognized different classes of nuisances. Those disturbances involving tangible but non-trespassory invasions such as smoke, odors, vibrations, excessive light or temperature, are well established. ${ }^{101}$ Sometimes courts have found nuisances in activities that threaten future physical invasions, such as stored explosives, fire hazards, and vicious dogs. ${ }^{102}$ Less tangible invasions are more difficult to shoehorn into nuisance. Apart from a few categories like funeral parlors, moral nuisances such as public nudity are found only occasionally, and purely aesthetic nuisances such as parking broken cars are almost never found at all. ${ }^{103}$ Inter-

${ }^{101}$ See, e.g., Grady v. Wolsner, 46 Ala. 381 (1871) (heat); Higgins v. Decorah Produce Co., 242 N.W. 109 (Iowa 1932) (odor); Sam Warren \& Son Stone Co. v. Gruesser, 209 S.W.2d 817 (Ky. 1948) (vibration); The Shelburne, Inc. v. Crossan Corp., 122 A. 749 (N.J. Ch. 1923) (light); Prosser and Keeton on Torts, supra note 79, $\$ 87$, at $619-20$ (identifying kinds of nuisances). For disturbances like excessive light, plaintiffs may have to contend with the defense that they are hypersensitive, see, for example, Amphitheaters, Inc. v. Portland Meadows, 198 P.2d 847, 853 (Or. 1948). Very few cases, however, have found a nuisance exclusively for excessive light, see Kristen M. Ploetz, Light Pollution in the United States: An Overview of the Inadequacies of the Common Law and State and Local Regulation, 36 New Eng. L. Rev. 985, 1006 (2002).

${ }^{102}$ Prosser and Keeton on Torts, supra note $79, \S 87$, at 620 (citing cases).

${ }^{103}$ Id. $\$ 86$, at 626 ; Smith \& Fernandez, supra note 12, at 54-55 (lamenting that "courts continue to deny relief for injury to aesthetic interests of residential landowners") (footnotes omitted); id. at 66 (asserting that "[t]hroughout the evolution of nuisance law, courts have almost unanimously refused to recognize actions for aesthetic nuisance" and citing cases); see also infra note 104. A few courts have found aesthetic nuisance. See, e.g., Allison v. Smith, 695 P.2d 791, 788 (Colo. Ct. App. 1984) (holding that storage of disused cars and other junk near property line was a nuisance for which an appropriate remedy was a permanent injunction); Foley v. Harris, 286 S.E.2d 186, 191 (Va. 1982) (finding that storage of wrecked cars on lots in subdivision constituted a nuisance); John Copeland Nagle, Moral Nuisances, 50 Emory L.J. 265, 282-83 (arguing that courts are beginning a trend away from traditional rejection of aesthetic nuisance clainis); Note, Aesthetic Nuisance: An Emerging Cause of Action, 45 N.Y.U. L. Rev. 1075, 1076-80 (1970) (arguing that there are signs that courts may 
estingly, courts routinely deny relief for aesthetic nuisances even where the impact on the market value of the plaintiff's land is obvious and does not present problems of proving damages.

Modern commentators, by contrast, are quite favorable to the idea of aesthetic nuisance, because they do not see nuisance as tethered to cheap, rough informational variables relating to physical location. In their more tort-like approach, inspired by the law of accidents, they perceive that the harms from aesthetic nuisances are no less real than are other, more tangible, harms. As a result, modern commentators believe that such conflicts should be as amenable to judicial intervention as other more traditional nuisances. ${ }^{104}$ This makes sense on the benefit side, which relates to what harms might be abated, but ignores significant elements of information costs. Because impairments of aesthetic values are more difficult to meter than are noises, heat, and so on, an informationcost theory leads us to expect a lesser reliance on finely tailored governance in this area.

Focusing on the benefits of addressing individuated activities, law and economics differs from nuisance law with its traditional exclusion-like concern with the locus of activities. In his landmark social cost article, Coase assumes a very realist picture of property, particularly where property intersects with the law of torts. ${ }^{105}$ To Coase, the economic problem of externalities was essentially one of conflicting resource use. From an economist's point of view, the set of uses that maximizes the overall value of all resources should be chosen. To illustrate the problem, Coase took nuisance disputes drawn from nineteenth-century English cases and analyzed them in terms of the economic problem of achieving the highest value use

be beginning to move away from flat rejection of all aesthetic claims to a position that aesthetic nuisance ordinarily will not be actionable).

${ }^{104}$ See, e.g., Robert D. Dodson, Rethinking Private Nuisance Law: Recognizing Aesthetic Nuisances in the New Millennium, 10 S.C. Envtl. L.J. 1, 3 (2002) (suggesting that "an aesthetic nuisance should be recognized and treated like any other nuisance case"); Smith \& Fernandez, supra note 12, at 54-55 (asserting that "[t]he bases upon which courts continue to withhold recognition of aesthetic nuisance actions lack both economic justification and legal coherence").

${ }^{105}$ Coase, supra note 1 , at 8-15 (contrasting unfavorably the reasons given by judges in hallmark nuisance cases with proper economic analysis in terms of choices between valued activities); see also Merrill \& Smith, What Happened to Property in Law and Economics?, supra note 3, at 366-71 (arguing that Coase's approach to land use conflict reflects a hyperrealist conception of property). 
of resources. In doing so, Coase assumed that property is the result of decisions over use-conflicts and that property is, in essence, a list of use rights. ${ }^{106} \mathrm{~A}$ new conflict emerges and is decided, awarding one more use-right stick to the bundle of one of the conflicting parties. Consider Coase's most famous example, Sturges v. Bridgman, ${ }^{107}$ the conflict between a confectioner making noise and vibration and the doctor who recently built his examination room next to the common wall. ${ }^{108}$ Coase considers the causation to be reciprocal-the doctor's use causes the conflict just as much as the confectioner's-and believes that the problem is to resolve the useconflict in such a way that the land is put to its highest use. In the absence of transactions, the court's word on this will be final. ${ }^{109}$

The Sturges court decided for the plaintiff doctor largely because the doctor, in building the examining room, was doing something to which he was entitled, whereas the confectioner was sending vibrations across the boundary between the two parcels. This seems question-begging or arbitrary. I argue that in this situation, as in many nuisance cases, Coase's observation about the reciprocal nature of causation, while correct in a theoretical sense, is not particularly helpful in deciding actual disputes. In fact, the treatment of land-use conflicts under nuisance and easement law reflects how deeply entrenched the locational approach is. In Sturges, for example, the defendant confectioner's main argument was not that there was no nuisance-everyone agreed that there was one-but that the nuisance had been occurring for longer than the period required to acquire an easement by prescription. Thus, there was a large degree of consensus on what constituted a legally cognizable harm, and the disagreement centered on questions such as whether Dr. Bridgman could have brought a nuisance suit before he built his examination room. The fact that the harm emanated from Sturges's land onto Bridgman's meant that there was a strong presumption that there was a nuisance, and there was a need to think in terms of an easement, a right in someone else's

${ }^{106}$ See Merrill \& Smith, What Happened to Property in Law and Economics?, supra note 3 , at $366-71$.

${ }^{107} 11$ Ch. D. 852 (CH. 1879) (Eng.); see Coase, supra note 1, at 8-10. For background on the case and an argument that the judges in that case were not directly interested in economic questions, see A.W. Brian Simpson, Coase v. Pigou Reexamined, 25 J. Legal Stud. 53, 89-92 (1996).

${ }^{108} 11 \mathrm{Ch}$. D. at 852-54.

${ }^{109}$ See Coase, supra note 1 , at 19. 
terms of an easement, a right in someone else's land. This accords with the strongly locational nature of the parties' rights under the exclusion regime. By contrast, in the Coasean world there would be no need for separate notions of nuisance and easement: Sturges would have a package of individualized use rights that might or might not include the right to send vibrations off in Bridgman's direction.

In actual land-use conflicts, much delineation cost can be saved by paying attention to those factors-where someone is doing something-that appear to be least relevant to Coase. Whereas for Coase the baseline that defines rights and duties is the relative value of two selected uses that are in conflict, the law defines a package of rights in terms of locations and actions that cross boundaries. This package has sometimes been termed "Blackstonian," and, although in its absolute form it is an exaggeration, it does describe the strong default package of rights emerging from the exclusion strategy. ${ }^{10}$ This package serves as a baseline for evaluating disputes that allows courts largely to avoid the ongoing evaluation of uses of the Coasean sort.

The question of baselines also highlights the mixture of exclusion and governance in nuisance law. Sturges is also famous for its statement of the "locality rule," under which the existence of a nuisance is partially determined with respect to where the activity occurs. ${ }^{11}$ As a governance regime, nuisance requires courts to look to

${ }^{110}$ See Ellickson, Property in Land, supra note 46 , at $1362-63$ (discussing what the author terms idealized "Blackstonian" bundle of property rights); Merrill \& Smith, What Happened to Property in Law and Economics?, supra note 3, at 392-94. Although Blackstone's language is, perhaps intentionally, overly absolute, he does describe a powerful default package. 2 William Blackstone, Commentaries *18-19 (explaining ad coelum maxim); id. at *2 (describing the right of property as "that sole and despotic dominion which one man claims and exercises over the external things of the world, in total exclusion of the right of any other individual in the universe"); see also, Robert P. Burns, Blackstone's Theory of the "Absolute" Rights of Property, 64 U. Cin. L. Rev. 67 (1985) (arguing that this "absolutist" reputation is inconsistent with the balance of Blackstone's treatment of property); Carol M. Rose, Canons of Property Talk, or, Blackstone's Anxiety, 108 Yale. L.J. 601, 604 (1998) (describing Blackstone's talk of an exclusive right to property as "a rhetorical figure describing an extreme or ideal type rather than reality").

${ }^{111} 11$ Ch. D. at 865; see also Campbell v. Seaman, 63 N.Y. 568, 577 (1876) (holding that "[a] use of property in one locality and under some circumstances may be lawful and reasonable, which, under other circumstances, would be unlawful, unreasonable and a nuisance"). 
the use and its context to see whether it is out of the ordinary in the locality. Traditionally, this test looked to the neighborhood context to discover what the proper "threshold" for nuisance should be, and this inquiry did not involve a court's weighing of the costs and benefits of various activities. ${ }^{112}$ But the classic modern reformulation of nuisance law tracing back to the First Restatement has advocated building some kind of utility balancing test into the locality standard. ${ }^{113}$ Commentators such as Robert Ellickson and Edward Rabin have argued for damages liability for activities deemed subnormal or unneighborly in light of community standards. ${ }^{114}$ This usually involves a use-by-use evaluation of activities and need not make reference to traditional notions of boundary invasions.

The traditional approach to the locality rule does not make boundary-based exclusion absolute, but is consistent with tolerations of invasions that reflect mutually beneficial forbearance. Invasions can be exempted from liability as long as the uses in a given area are relatively uniform and thus each landowner gets what Richard Epstein calls "implicit in-kind compensation" in the form of an ability by the (unsuccessful) plaintiff to engage in the complained-of use as well. ${ }^{115}$ The traditional locality rule had a strong

${ }^{112}$ See Bone, supra note 13, at 1159-60, 1160 n.126 (documenting opposition among nineteenth-century courts and commentators to balancing of the utilities in nuisance cases).

${ }^{113}$ Restatement (First) of Torts $\$ \S 822,826$ (1939).

${ }^{114}$ Robert C. Ellickson, Alternatives to Zoning: Covenants, Nuisance Rules, and Fines as Land Use Controls, 40 U. Chi. L. Rev. 681, 728-33 (1973) [hereinafter Ellickson, Alternatives to Zoning]; Edward Rabin, Nuisance Law: Rethinking Fundamental Assumptions, 63 Va. L. Rev. 1299, 1317-21 (1977). Ellickson employs neighborliness to define the prima facie case for nuisance:

A landowner who intentionally carries out activities, or permits natural conditions to develop, that are perceived as unneighborly under contemporary community standards shall be liable for all damages (measured by the diminution in the market value of plaintiff's land plus bonuses for diminutions in widely held subjective values) to all parties who are thereby substantially injured, and continuation of the activity may be enjoined by any party willing to compensate the landowner for any losses he suffers from that injunction.

Ellickson, supra, at 748. Ellickson's approach is to define the threshold for strict liability in terms of what is normal for the locality. This could be done on an activity-byactivity basis, or could rely, as I am arguing for here, more on exclusion, by asking how significantly borders were crossed.

${ }^{115}$ Epstein, Nuisance Law, supra note 14, at 88; see also Penner, Nuisance and the Character of the Neighbourhood, supra note 12 , at $6-7$ (relating the locality rule to 
flavor of live and let live; the locality mattered because each owner gained the right to do a similar activity. ${ }^{116}$ Likewise, as J.E. Penner argues, traditional English nuisance law was very unlikely to excuse any harm that caused physical damage to land. ${ }^{117}$ The physical damage can thus be regarded as a rough informational variable that tends to push nuisance back towards the exclusion end of the spectrum, in a manner very similar to the nuisance per se doctrine.

This question of baselines and the locality brings us to the famous maxim sic utere tuo ut alienum non laedas, "use your property in such a way as not to injure another's," which used to be the foundation of the law of nuisance. ${ }^{118}$ Since the realist era, the maxim has fallen somewhat out of favor because of its apparent question-begging quality. Specifically, we need to know what harms one has a right to be free from in order to apply the maxim, but what constitutes such harm is the question to begin with. ${ }^{119} \mathrm{I}$ would suggest that the maxim, which is often cited in cases of conflicting land use, is a shorthand for the exclusion strategy and its limited modification through governance rules. This strategy includes a heavier reliance on location and boundaries than would be

live and let live through the notion that the plaintiff and defendant gain the right to engage in the same sort of activities).

${ }^{116}$ See Bamford v. Turnley, 122 Eng. Rep. 27, 33 (Ex. Ch. 1862); Epstein, Nuisance Law, supra note 14 , at $87-88$ ("The locality rule, far from isolating the defendant's conduct from its environment, consciously evaluates its actionability in relationship to its surrounding circumstances. It thereby excuses certain invasions solely on the ground that other persons with sufficient frequency have committed like wrongs against other persons in the plaintiff's position."); Penner, Nuisance and the Character of the Neighbourhood, supra note 12, at 4-11 (explaining that "[r]ights to cause (non-actionable) annoyances are 'reciprocal' in the sense that every land owner has the same rights in this respect").

${ }_{117}$ Penner, Nuisance and the Character of the Neighbourhood, supra note 12 , at 9 (citing Halsey v. Esso Petroleum Co., 2 All E.R. 145, 150-51 (Q.B. 1961) (Eng.)).

${ }^{118}$ See, e.g., Vill. of Euclid v. Ambler Realty Co., 272 U.S. 365, 387 (1926) ("In solving doubts, the maxim sic utere tuo ut alienum non laedas, which lies at the foundation of so much of the common law of nuisances, ordinarily will furnish a fairly helpful clew."); Lussier v. San Lorenzo Valley Water Dist., 253 Cal. Rptr. 470, 473 (Cal. Ct. App. 1988) ("The basic concept underlying the law of nuisances is articulated in the ancient maxim sic utere tuo ut alienum non laedas, that is, so use your own as not to injure another's property.").

${ }^{119}$ See Lucas v. S.C. Coastal Council, 505 U.S. 1003, 1031 (1992) (criticizing invocation of sic utere maxim as conclusory); Hale v. Farmers Elec. Membership Corp., 99 P.2d 454, 456 (N.M. 1940) (holding that although sic utere is a good moral precept, it is useless as a grounds for decision because it does not determine any right or obligation, and citing cases and commentary to this effect). 
optimal if the delineation of rights were costless. The law defines property in land by delineating a location within which there is a strong (but not absolute) presumption that the owner can do what she wants. Where two owners with rights in nearby parcels come into conflict, the presumption is that there is a violation by the more active party, especially one sending physical objects, sound waves, vibrations, and so on across the boundary used in the definition of the other owner's property. These presumptions can be overcome if the intrusion is a de minimis nuisance, or if the locality is almost uniformly suited to a special use, or if the plaintiff is hypersensitive. ${ }^{120}$ The maxim sic utere simply refers to this background set of presumptions that piggyback on the locational definition of the property right.

\section{Remedies}

On the remedy side, the use of injunctions in nuisance law makes sense where exclusion is called for. Property rules are suited to protect the delegation involved in an exclusion regime. ${ }^{121}$ To implement a property rule, courts can just monitor the rough variable-such as entry - and impose liability without having to evaluate individual uses. Liability rules, by contrast, do involve measuring individual uses, and a liability rule regime involves a partial withdrawal of the delegation of use-determination from property owners. Thus, to the extent that this delegation is worth preserving, we should expect property rules in the law of nuisance. Traditionally, injunctions were freely available for substantial nuisances. ${ }^{122}$

As multiple use becomes more important, a governance regime of some sort should tend to emerge, either by contract, regulation,

${ }^{120}$ A hypersensitive plaintiff will not have a remedy for irritations that would not disturb an ordinary landowner. On the hypersensitivity defense, see, for example, Amphitheaters, Inc. v. Portland Meadows, 198 P.2d 847, 853 (Or. 1948). See also Ellickson, Alternatives to Zoning, supra note 114, at 752 (noting that one reason hypersensitive plaintiffs "receive little sympathy is that they were probably the best avoiders of the losses they suffered").

${ }^{121}$ See Smith, Property and Property Rules, supra note 24.

${ }^{122}$ A leading case of automatic injunctive relief for nuisance was Whalen $v$. Union Bag \& Paper Co., 101 N.E. 805 (N.Y. 1913). See also Bone, supra note 13, at 1178-79 (discussing traditional approaches to injunctive relief in nuisance cases); infra Section IV.D. 
or modification of common-law rules. As a historical matter, as resource use became more intense and specialized in the course of the nineteenth century, nuisance law became more articulated. Later land-use regulations and pollution controls then partially displaced nuisance with ever more detailed governance regimes. ${ }^{123}$ With the increase in importance of multiple use, though, the cost of achieving this tailoring is likely to increase because the supply curve for institutions shifts outward. In such a dynamic setting, the benefits and the costs of both exclusion and governance can shift in tandem. But if the cost of acquiring and acting on information about uses does not shift, rising resource values should lead to increasing precision of rights. For a given resource, this means a tendency to move to supplement exclusion with governance rules. With rising resource values, we might expect an increase in governance or an increasing use of exclusion based on more finegrained parcels, in a sort of enclosure movement. ${ }^{124}$

In a static sense, the difficulty of determining damages relating to use can also push in the direction of injunctions, as informationcost theory would predict. Traditionally, equitable remedies were available when the remedy at law was inadequate or when a party suffered an irreparable injury, that is one for which damages would not be an adequate remedy. ${ }^{125}$ The irreparable injury rule is consis-

${ }^{123}$ See, e.g., Robert D. Grinder, The Battle for Clean Air: The Smoke Problem in Post-Civil War America, in Pollution and Reform in American Cities, 1870-1930, at 83, 93 (Martin V. Melosi ed., 1980); Rose, Rethinking Environmental Controls, supra note 35 , at 25-26. For an argument that a reformed nuisance law should have an important role to play in land-use conflicts and a proposal for local nuisance boards to administer it, see Ellickson, Alternatives to Zoning, supra note 114, at 762-71.

${ }^{124}$ Smith, Exclusion versus Governance, supra note 3, at S475-76, S481. A move to smaller parcels, for example in the enclosure of a commons, is another method of increasing precision.

${ }^{125}$ See Terrace v. Thompson, 263 U.S. 197, 214 (1923) ("Equahity jurisdiction will be exercised to enjoin the threatened enforcement of a state law which contravenes the Federal Constitution wherever it is essential in order effectually to protect property rights and the rights of persons against injuries otherwise irremediable."). The inadequacy or irreparable-injury rule is usually stated to be a prerequisite to equitable relief. See, e.g., Knaebel v. Heiner, 663 P.2d 551, 553 (Alaska 1983); Brownfield v. Daniel Freeman Marina Hosp., 256 Cal. Rptr. 240, 243 (Cal. Ct. App. 1989); In re Marriage of Strauss, 539 N.E.2d 808, 812 (Ill. App. Ct. 1989); Borom v. City of St. Paul, 184 N.W.2d 595, 598 (Minn. 1971). But there is some doubt as to whether the rule has any bite. See Douglas Laycock, The Death of the Irreparable Injury Rule 45, 22-23 (1991) (arguing that the American legal system does not prefer damages and that the irreparable injury rule has little effect). 
tent with this cost structure. In nuisance situations where determining damages based on use is costly, we expect a more exclusionbased rule because it is likely to be most cost-effective. And in this case, much of the cost of delineation is borne by the judges making the rules. It may be that in such situations the rule is not as mechanical as in classical trespass (as Merrill argued), but the irreparable injury rule is hardly less exclusion-like where it applies. And this is what we expect; in high measurement-cost situations, an exclusion-type approach is likely to be most cost-effective through a larger range of activities.

A system resting on a foundation of exclusion economizes on information costs because it defines rights in an implicit and sweeping way. By resolving all but the most difficult and high-stakes cases in terms of who crossed a boundary-with objects or sound waves or odors or so forth-the law can rely on a basic and cheap package of rights with a high degree of salience and ease of processing. Although it is hard to say exactly when to depart from this approach, ${ }^{126}$ the maxim sic utere and the nuisance cases reflect a very strong presumption against the Coasean and realist use-by-use approach.

On the information-cost theory, nuisance and liability rules are used to fine-tune the basic exclusionary regime. If so, it should not be surprising that nuisance retains much of the flavor of-and certainly does not repudiate-the basic exclusionary regime that it supplements. Land is a convenient and low-cost anchor for a wide range of rights, because an exclusionary regime-and its refinements-can rely on highly stable and salient locational variables. For courts and dutyholders, making sense of who owes what duties to whom is far easier when there is a strong presumption that the package of rights is defined around land rather than as a list of use rights. To be sure, on the list-of-use-rights approach, the most efficient result could be achieved in each of the potential use-conflicts, but this is likely to be very costly indeed.

\section{THE RARITY OF RULE 4}

Nuisance analysis in contemporary law and economics has been profoundly shaped by Guido Calabresi and A. Douglas Melamed's

${ }^{126}$ See infra Part IV. 
famous framework of property rules and liability rules as alternative methods of protecting "entitlements."127 Calabresi and Melamed took as their primary example the classic nuisance dispute, and this has been the practice in this corner of the law-andeconomics literature ever since. ${ }^{128}$ It is not hard to see why. Calabresi and Melamed's framework, like Coase's, presupposes the list-of-uses vision of property. ${ }^{129}$ Nuisance comes closer to implementing the use-by-use approach than do other aspects of property law but, as I argue, law and economics has tended to overlook the exclusionary elements in nuisance law. ${ }^{130}$ It has also missed the role that exclusion plays in determining how entitlements are protected.

Calabresi and Melamed noticed two cross-cutting distinctions in the law, one relating to the nature of the entitlement's protection and the other relating to who holds the entitlement in the first place. As for protection, the law sometimes gives someone an entitlement but allows others to take it as long as the taker pays officially determined damages. Calabresi and Melamed called this a $l i$ ability rule. ${ }^{131}$ Examples include eminent domain and the law of negligence. ${ }^{132}$ By contrast, a property rule protects the entitlement with supracompensatory damages or injunctions, so that a transfer must occur with the consent of the current holder. ${ }^{133}$ The possibility of damages versus injunctions is a major issue in nuisance disputes, one to which I return in Section IV.D.

Cutting across the property rule-liability rule distinction is the question of who has the entitlement. If causation is reciprocal the potential assignment of entitlements is as well, and Calabresi and Melamed argued that antecedent to the question of protecting entitlements is to whom and under what circumstances collectively to

\footnotetext{
${ }^{127}$ Calabresi \& Melamed, supra note 2.

${ }^{128}$ See supra note 2 ; infra note 144.

${ }^{129}$ See Merrill \& Smith, What Happened to Property in Law and Economics?, supra note 3 , at 379-81.

${ }^{130}$ See id. at 394-97.

${ }^{131}$ Id. at 1092.

${ }^{132}$ Id. at 1106-07 (eminent domain); id. at 1108-09 (law of accidents).

${ }^{133}$ Id. at 1092. Calabresi and Melemed also proposed a third category of inalienability rules, under which an entitlement is nontransferable even between a willing buyer and willing seller. Id. at 1092-93. Inalienability rules are not characteristic of the common law of nuisance.
} 
"grant" the entitlement. ${ }^{134}$ In a pollution conflict the "entitlement" could be either in the pollutee or the polluter. ${ }^{135}$

Either of the two parties in a resource conflict could hold the entitlement with either form of protection, leading to four possible situations. First, the victim could have the right to be free from pollution with property rule protection in the form of an injunction or supracompensatory damages (Rule 1). Second, the victim could have the entitlement to be free from pollution, but in this case only protected by a liability rule in the form of compensatory damages (Rule 2). Third, the law could afford the polluter an "entitlement" to pollute, protected by a property rule (Rule 3 ). One might imagine a polluter able to get an injunction against a pollutee who refuses to accept pollution, but Calabresi and Melamed seem to have in mind a simple inability of the pollutee to stop the polluter. I return to the nature of the polluter's entitlement shortly. Fourth and finally, the cross-cutting distinction of protection and location of the entitlement generates a final scenario where the polluter would have the entitlement, but protected only by a liability rule (Rule 4). In other words, under Rule 4, the pollutee could sue the polluter but would have to pay the polluter's costs of abating or shutting down. ${ }^{136}$ This final rule, termed a "compensated injunction" by Robert Ellickson, was a purely theoretical prediction. ${ }^{137}$ Only the first three can be found extensively in the case law. ${ }^{138}$

The deduction of the possibility of the fourth rule, the famous Rule 4, was the most startling and, to nuisance commentators, one of the most influential aspects of Calabresi and Melamed's framework. ${ }^{139}$ Under Rule 4, the pollutee could enjoin the polluter but

\footnotetext{
${ }^{134}$ Id. at $1090-93$.

${ }^{135}$ Id. at 1090 .

${ }^{136}$ Id. at $1115-16$.
}

${ }^{137}$ Ellickson, Alternatives to Zoning, supra note 114 , at 738 n.202. Calabresi and Melamed did assert that "[i]ndeed, in one form or another, [Rule 4] may well be the most frequent device employed," Calabresi \& Melamed, supra note 2, at 1117, but only provided their interpretation of emincnt domain over nonconforming uses and ecological easements as possible examples, id. at 1117 n.58.

${ }^{138}$ See Calabresi \& Melamed, supra note 2, at 1115-17.

${ }^{139}$ Id. at 1116 ("The very statement of [Rules 1-3] in the context of our framework suggests that something is missing. Missing is a fourth rule ...."). Guido Calabresi has pointed out that, unknown to him and Melamed at the time, James Atwood had suggested in a student note the possibility of a remedy like Rule 4 three years before their article. Guido Calabresi, Remarks: The Simple Virtues of The Cathedral, 106 
would have to pay damages for the polluter's cost of abating or shutting down. What was even more surprising was the nearly simultaneous adoption of something like Rule 4 by the Arizona Supreme Court in the coming-to-the-nuisance case of Spur Industries, Inc. v. Del E. Webb Development Co. ${ }^{140}$ In the Spur case, the Arizona Supreme Court required a plaintiff developer to pay damages to a defendant feedlot that would be shut down by an injunction in its nuisance suit. ${ }^{141}$ Rule 4 has found great favor with commentators on nuisance law ${ }^{142}$ and among proponents of liability rules, leading to many further elaborations. ${ }^{143}$ Nevertheless, Rule 4 has never been used in a nuisance case since Spur, and the Spur case has not heralded a new approach to liability. The information-cost theory of exclusion can help explain why. ${ }^{14}$

Mostly commentators have treated the lack of Rule 4 treatment as a curious gap in the law, perhaps to be explained by the administrative costs of gathering relevant parties, valuing abatement costs, and apportioning liability. ${ }^{145}$ In a rare exception, Richard Epstein criticizes Rule 4 as destabilizing the property system. ${ }^{146}$ For Epstein, liability rules are only justified when the holdout risk clearly out-

Yale L.J. 2201, 2204 (1997) (citing and discussing James R. Atwood, Note, An Economic Analysis of Land Use Conflicts, 21 Stan. L. Rev. 293, 315 (1969)).

${ }^{140} 494$ P.2d 700, 708 (Ariz. 1972) (en banc).

${ }^{141} 494$ P.2d at 708 (en banc).

${ }^{142}$ See, e.g., Ellickson, Alternatives to Zoning, supra note 114, 744-46 (arguing for use of Rule 4 as a second stage option for the plaintiff when a nuisance defendant opts to pay Rule 2 damages and continue the nuisance); Jeff L. Lewin, Compensated Injunctions and the Evolution of Nuisance Law, 71 Iowa L. Rev. 775, 827-31 (1986) (arguing for limited use of compensated injunctions in the interest of fairness); Rabin, supra note 114, at 1339-46 (advocating compensated injunctions in cases of deserving plaintiffs only).

${ }^{143}$ See, e.g., Ayres \& Goldbart, Optimal Delegation, supra note 2; Krier \& Schwab, supra note 2; Saul Levmore, Unifying Remedies: Property Rules, Liability Rules, and Startling Rules, 106 Yale L.J. 2149 (1997).

${ }^{144}$ This despite Calabresi and Melamed's assertion that "in one form or another, [Rule 4] may well be the most frequent device einployed." Calabresi \& Melamed, supra note 2, at 1117 .

${ }^{145}$ See, e.g., id. at 1122 \& n.62; Krier \& Schwab, supra note 2, at 475-77; Lewm, supra note 142 , at $790-91$.

${ }^{146}$ Richard A. Epstein, A Clear View of The Cathedral: The Dominance of Property Rules, 106 Yale L.J. 2091, 2103-05 (1997) [hereinafter Epstein, A Clear View] (referring to Rule 4 as posing an "enormous risk," "grotesque," "wholly subversive of any account of ordinary property rights," and "Inisguided"). 
weighs the risk of undercompensation. ${ }^{147}$ But commentators favoring liability rules do not see undercompensation as inevitable. They further cite the benefits of allowing one party to choose who winds up using the entitlement even where, for distributional reasons, the other party should not have to bear the entire loss. ${ }^{148}$

The information-cost theory allows a fuller explanation of the rarity of Rule 4 . The deduction that Calabresi and Melamed performed rests on the very Coasean assumption that causation is reciprocal and that locating "the" entitlement in either party is the mirror image of giving it to the other party. This premise, however, is questionable at best. Consider Rules 1 and 3, which accord property rule protection to the polluter and pollutee, respectively. If the pollutee has the entitlement under a property rule (Rule 1), then the pollutee can sue in nuisance to enjoin the polluter whenever sufficient odor comes onto the pollutee's land and disturbs her in the quiet enjoyment of her land. But what if things were decided the other way? Does the polluter have "the entitlement to pollute?"

\section{A. A Right to Pollute?}

Here some Hohfeldian analysis is helpful. ${ }^{149}$ The pollutee who has property rule protection (Rule 1) has a claim-right based on her package of rights to quiet enjoyment of her land. The pollutee can sue to enforce the correlative duty of the polluter not to pol-

${ }^{147}$ Id. at 2094.

${ }^{148}$ See Ronen Avraham, Modular Liability Rules 3-4 (John M. Olin Center for Law \& Econ., Working Paper No. 01-003, 2001) (referring to recent studies that have "demonstrated how [1]iability [r]ules achieve higher social welfare by harnessing one party's private information about its own valuation to the process of optimally allocating the entitlement between the parties"); Ayres \& Goldbart, Optimal Delegation, supra note 2 , at 9 (asserting that "from an efficiency perspective liability rules are a means by which an imperfectly informed court can delegate the allocative choice to private litigants who potentially have superior allocative information").

${ }^{149}$ Jeanne Schroeder applies Hohfeldian analysis and suggests that the polluter does not have a right to pollute for a different reason: the polluter's entitlement does not require affirmative action on the part of the putative dutyholder. See Jeanne $L$. Schroeder, Three's a Crowd: A Feminist Critique of Calabresi and Melamed's One View of the Cathedral, 84 Cornell L. Rev. 394, 438 (1999). She diagnoses the problem with Calabresi and Melamed's framework differently, altlougl her objection that there is no single thing to which the polluter or the pollutee miglit be entitled is consistent with the analysis here. 
lute. But if, as under Rule 3, the polluter can pollute, what is the nature of its entitlement? Does it have a "right to pollute," as Calabresi and Melamed and all proponents of the liability rule assume ${ }^{150}$ Imagine that the pollutee has technological means-giant fans perhaps - to prevent the odor from entering her land. Assume that this causes the pollution to back up in the factory preventing it from operating properly. Could the polluter in our legal system sue to enjoin the pollutee's operation of the fans?

Very probably the polluter could not sue, which indicates that the polluter in the Rule 3 scenario is exercising a privilege, not a right, to pollute. In terms of Hohfeld's famous classification of jural relations, a privilege or liberty correlates with a "no-right" in the other party: If $A$ has a privilege to pollute, $B$ cannot sue to stop $A$ from polluting, but $A$ cannot call upon the law's aid to ensure the ability to pollute. By contrast, if $A$ had a right or claim to pollute, then $B$ would be under a correlative duty to accept pollution. ${ }^{151} \mathrm{But}$ far from granting the polluter a right to pollute, the law gives the right to the pollutee to take feasible efforts to block the pollution, even if this causes inconvenience to the polluter. The problem for the pollutee is that such measures are usually not feasible. ${ }^{152} \mathrm{De}$ -

\footnotetext{
${ }^{150}$ See, e.g., Ayres \& Goldbart, Optimal Delegation, supra note 2, at 46 (discussing the "right to pollute" in the property rule versus liability rule framework); Calabresi \& Melamed, supra note 2, at 1118-19 (discussing the "right to pollute"); Kaplow \& Shavell, supra note 2, at 719 n.14 (noting alternative of protecting a polluter's right to pollute with a property rule); Rabin, supra note 114, at 1343 (arguing that it is an oversimplification to speak of a "right to pollute" because the polluter "actually has only a qualified right to pollute in quantities reasonable for the time and place, given the present state of the art of pollution abatement"). For a very careful formulation of how the failure of a plaintiff's suit against a polluter results "in effect" that the defendant has "enjoined" the plaintiff and enjoys "what amounts to a property right," see Kenneth S. Abraham, The Forms and Functions of Tort Law 176-77 (2d ed. 2002).

${ }^{151}$ See Hohfeld, supra note 31, at 8-9. In the hypothetical scenario, the fans merely prevent the smoke from coming onto the fan-operator's land. Blowing back smoke that has already entered land might be a situation of reciprocal nuisance.

${ }^{152}$ The treatise upon which Coase relied states unequivocally that:

[T]he right to a lateral passage of air, as well as to a flow of water, superadds a privilege to the ordinary rights of property, and is quite distinct from that right which every owner of a tenement, whether ancient or modern, possesses to prevent his neighbour transmitting to him air or water in impure condition; this latter right is one of the ordinary incidents of property, requiring no easement to support it, and can be countervailed only by the acquisition of an easement for that purpose by the party causing the nuisance.
} 
spite Coase's best efforts to portray the nuisance cases as reciprocal in more than just theory and to find that judges had some implicit understanding of the "economic problem," the access to air cases turn out, on closer examination, to be very asymmetric.

Under the English law Coase examined, there was no right to the free circulation of air-contrary to what one might have expected on the reciprocal view of causation. For example, in Bryant $v$. Lefever, the defendants tore down their house, erected a new taller one, and stacked lumber on the roof. ${ }^{153}$ Thereafter, the smoke would back up in the chimneys of the plaintiff's adjacent house. Coase discusses this case at length and emphasizes that although the smoke nuisance was caused by both parties, the judges found no liability because they took too narrow a view of the case:

Who caused the smoke nuisance? The answer seems fairly clear. The smoke nuisance was caused both by the man who built the wall and by the man who lit the fires. Given the fires, there would have been no smoke nuisance without the wall; given the wall, there would have been no smoke nuisance without the fires. Eliminate the wall or the fires and the smoke nuisance would disappear. On the marginal principle it is clear that both are responsible and both should be forced to include the loss of amenity due to the smoke as a cost in deciding whether to continue the activity which gives rise to the smoke...

The judges' contention that it was the man who lit the fires who alone caused the smoke nuisance is true only if we assume that the wall is the given factor. This is what the judges did by deciding that the man who erected the higher wall had a legal right to do so. ${ }^{154}$

Gale on Easements 241 (Michael Bowles ed., 13th ed. 1959). Notice that the lack of a right to pollute and the right to keep off pollution are both consistent with the locational approach of an exclusionary regime. See also John Pugh-Smith et al., Neighbours and the Law $\$ 2.26$, at 56 (3d ed. 2001) ("[T]he right to prevent the access of impure air is a right of property in itself and does not require an easement to uphold the injured party's rights." (citing Curriers' Co. v. Corbett, 46 Eng. Rep. 1119 (L.R.-Ch. 1865))).

${ }^{153} 4$ C.P.D. 172, 175-76 (1879) (Eng.). Coase discusses this case in his famous treatment of nuisance. Coase, supra note 1 , at 11-13.

${ }^{154}$ Coase, supra note 1 , at 13 . 
Indeed, the judges noted that the defendants had a right to build and, although their right to build was subject to the rights of others, the cases did not support a generalized right to the circulation of air. ${ }^{155}$ Further, they noted that a prescriptive easement (affording its owner the ability to require the owner of the servient estate to maintain the free flow of air) based on having a house would be too vague and uncertain. ${ }^{156}$ Lord Justice Bramwell couched his conclusion in terms of causation:

No doubt there is a nuisance, but it is not of the defendants' causing. They have done nothing in causing the nuisance. Their house and their timber are harmless enough. It is the plaintiff who causes the nuisance by lighting a coal fire in a place the chimney of which is placed so near the defendants' wall, that the smoke does not escape, but comes into the house.... But (what is in truth the same answer), if the defendants cause the nuisance, they have a riglit to do so.... "Sic utere tuo ut alienum non laedas" is a good maxim, but in our opinion the defendants do not infringe it: the plaintiff would if le succeeded. ${ }^{157}$

Coase notes that if the defendant wall-builder in the case had suffered damage to his timber from the smoke,

[t]lie case would then liave closely paralleled [the physicianconfectioner case of] Sturges $v$. Bridgman and there can be little doubt that the man who lit the fires would liave been liable for the ensuing damage to the timber, in spite of the fact that no damage liad occurred until the higlı wall was built by the man who owned tle timber. ${ }^{158}$

Interestingly, Coase implicitly admits that, however unjustified in his opinion the judges' views were economically, they were very predictable on the basis of locationally defined property.

Coase's patience with the judges' reasoning wears especially thin when it comes to the final nuisance case he discusses, Bass v. Greg-

${ }^{155}$ See, e.g., Bryant, 4 C.P.D. at 176 (holding that "a right the wind should not be checked" is constrained by the rights of neighbors "to use their property in the various ways in which property is commonly and lawfully used").

${ }^{156} \mathrm{See}$ id. at 178 . On acquiring easements for the passage of air through "defined channels," see infra note 161 and accompanying text.

${ }^{157}$ Bryant, 4 C.P.D. at 179.

${ }^{158}$ Coase, supra note 1 , at 13 . 
ory, where the plaintiff claimed a right to have air pass from his cellar brewery out through the defendant's disused courtyard well..$^{159}$ Because the passage of air was through "a defined channel" and had been occurring for at least forty years, the court, in contrast to the result in Bryant $v$. Lefever, decided that the plaintiff had an easement for the passage of air, using the notorious fiction that the long acquiescence of the defendant was evidence of a "lost grant" of the easement. ${ }^{160}$ Coase, noting the contrast to Bryant, dismisses the notion of a "defined channel" with the observation that "[a]n economist might be tempted to add "but the air moved all the same.""161 To Coase, the legal doctrines do not address the economic problem:

The reasoning employed by the courts in determining legal rights will often seem strange to an economist because many of the factors on which the decision turns are, to an economist, irrelevant. Because of this, situations which are, from an economic point of view, identical will be treated quite differently by the courts. The economic problem in all cases of harmful effects is how to maximise the value of production. In the case of Bass $v$. Gregory fresh air was drawn in through the well which facilitated the production of beer but foul air was expelled through the well which made life in the adjoining houses less pleasant. The economic problem was to decide which to choose: a lower cost of beer and worsened amenities in adjoining houses or a higher cost of beer and improved amenities. In deciding this question, the "doctrine of lost grant" is about as relevant as the colour of the judge's eyes. ${ }^{162}$

To Coase, again, questions of "property" are really the outcome of decisions about more valuable uses, and property is the collection of use rights that emerges from this process. In effect, the judge is a miniature central planner rather than the enforcer of antecedent

${ }_{159}^{15} 25$ Q.B.D. 481 (1890) (Eng.).

${ }^{160}$ English judges would presume a lost grant of an easement for what were in effect prescriptive easements, but this fiction has been abandoned in England and in most American states. Robert Megarry \& H.W.R. Wade, The Law of Real Property 876-78 (5th ed. 1984); 7 Thompson on Real Property $\S 60.03(b)(6)(i i)$, at 435 (David A. Thomas ed., 1994).

${ }^{161}$ Coase, supra note 1 , at 14

${ }^{162}$ Id. at 15. 
rights to things good against the world, that is, property in the traditional sense.

\section{B. Information Costs and Rights to the Flow of Air}

I argue that the law's approach to smoke and air circulation is not just predictable but reflects the low information costs of defining rights using exclusion for the basics and governance for the fine-tuning of use-entitlements. The presumption is that people get to exclude unwanted objects, odors, and so on from the column of space around the land as defined by the ad coelum rule, and that this implicitly protects a privilege-but not a right-to engage in activities such as lighting fires and polluting. ${ }^{163}$ In Bryant, the defendant wall-builder and timber-stacker did not move anything from its land to the plaintiffs'. This approach based on location and directional causation may be arbitrary in some theoretical sense and would be irrelevant to the economic choice of which activity should ultimately "win out"-as long as information costs are suppressed.

Once information costs enter the picture, the situations in Bryant v. Lefever and Bass v. Gregory are not, pace Coase, economically identical. Arguably, situations of air traveling in "defined channels" for lengthy periods of time are a sensible exception to the basic exclusionary regime: The defined channel makes the right claimed more obvious, thereby reducing information costs to the supposed dutyholder. Where the benefits of detailed dispute resolution exceed the costs of doing so (by party contracting or judgemade law), we might expect such exceptions. ${ }^{164}$ In Coase's accessto-air cases, the air may move "all the same," but the claimed dutyholder would not notice just the same. In ordinary cases, however, when judges stick to the strong presumptions in the exclusionary regime based on the ad coelum rule and pay attention to who moved what where, their approach does make economic sense. ${ }^{165}$ The stakes have to be very high and the parties' ability to

\footnotetext{
${ }^{163}$ See supra note 80 and accompanying text.

${ }^{164}$ Another example would be the airplane overflight cases; the stakes are very high and a judge-made governance-style exception to the ad coelum rule makes eminent sense. See supra note 80 .

${ }^{165}$ I leave open the question of how conscious the judges are about this. After all, if the information-cost theory is correct, then the same information costs would shape
} 
contract quite limited before a court-supplied governance regime of use-by-use determination is worthwhile.

Again, the delineation of rights has a highly locational flavor, as expected on the information-cost theory. In the nuisance cases, the package of rights does not include even the right of access to air. Where air is blocked, nothing, not even an odor, has passed from one parcel to another. By contrast, pollutees who do receive "things" onto their land have a right to take action (to the extent feasible) to prevent the pollution from entering their land. And when the polluter has a true entitlement to pollute, the issue is framed in terms of whether the polluter has an easement-whether a right has been carved out of the pollutee's package and given to the polluter. ${ }^{166}$

In the case of air, the pollutee usually cannot prevent, in selfhelp fashion, the pollution from entering her land, and thus a polluter who has a privilege to pollute is easy to confuse with one who has a right to pollute. A better test case is the law of surface water, because water and water pollution are easier to divert. Accordingly, the law has faced more squarely the question of liability for diverting diffuse surface water (water outside a watercourse). Basically, the English and "classic" American doctrine applying to diffuse surface water is the "common enemy" doctrine, under which each landowner has an absolute right to defend against inflows of these waters-to combat the common enemy of surface watereven if this causes damaging flooding to other landowners. ${ }^{167}$ This doctrine is one of exclusion. The owner has a privilege to keep out the "common nuisance" from the column of space defined by the ad coelum rule. Notice, though, that if one landowner dams his

the types of customs that the law built on as well as people's basic "common sense" view of causation that law and economics joins legal realism in disdaining.

${ }^{166}$ The formulation in the text in terms of carving out and giving is particularly apt when courts face grantor-grantee situations and where courts use the fiction of the lost grant. See supra note 160 .

${ }^{167}$ Argyelan v. Haviland, 435 N.E.2d 973, 975-77 (Ind. 1982); Slade Luther v. Winnisimmet Co., 63 Mass. (9 Cush.) 171, 172-73 (1851) (adopting the common enemy rule for the first time); Bowlsby v. Speer, 31 N.J.L. 351, 353-55 (N.J. 1865); Kossoff v. Rathgeb-Walsh, Inc., 148 N.E.2d 132, 134-35 (N.Y. 1958); 2 Waters and Water Rights $\S 10.03(\mathrm{~b})(1)$ (Robert E. Beck ed., 1991); 5 Waters and Water Rights $\S 59.02(\mathrm{~b})(2)$ (Robert E. Berk ed., 1991) (citing first American case and quick adoption by English courts); Stanley V. Kinyon \& Robert C. McClure, Interferences with Surface Waters, 24 Minn. L. Rev. 891, 898-904 (1940). 
land and causes the surface water to flow to a second owner's land, the second owner is similarly privileged to dam her land and send the water back. The first landowner cannot sue the second to prevent this flow-indeed neither can sue the other ${ }^{168}$-indicating that each enjoys a Hohfeldian privilege, and not a right, to dispose of unwanted water. This is a regime of exclusion if there ever was one: The rights of each party are defined in a strictly locational manner ${ }^{169}$ and have the effect of keeping the privilege to repel groundwater "a submerged part of a general estate in the land,",170 as exclusion does generally by protecting privileges of (undefined) use with a (defined) right to exclude from a column of space around the land. More recently, as conflicts have arguably become more intense, the common enemy doctrine has been supplemented in those jurisdictions still adhering to it with several governancelike limitations. ${ }^{171}$ It has similarly been replaced elsewhere by judicial doctrines closer to the governance end of the spectrum. ${ }^{172}$

${ }^{168} 5$ Waters and Water Rights, supra note $167, \S 59.02(\mathrm{~b})(2)$.

${ }^{169}$ See 2 Waters and Water Rights, supra note $167, \S 10.03(\mathrm{~b})(1)$ ("[T] enemy rule treated the diffused water as a nuisance which all landowners were permitted to dispose of as each owner choose [sic], so long as they took measures on their own land and not on that of their neighbors.") (citations omitted).

${ }^{170} 3$ Waters and Water Rights, supra note $167, \S 20.03$.

${ }^{171} 5$ id. $\$ 59.02(b)(2)$.

${ }^{172}$ Although it exceeds the scope of this Article, it is worth noting that more recent developments in surface water law fit very well with the dynamic theory of exclusion versus governance. As resource conflict has become more intense, many courts adopted the civil-law doctrine of natural flow or, more recently, the reasonable use doctrine. The natural flow doctrine is a compromise between exclusion and governance; it establishes a flat rule that each landowner must leave the drainage in its natural state, thus giving each landowner a servitude over the other for natural flow. 2 id. $\S$ 10.03 (b)(2); 5 id. $\$ 59.02$ (b)(3); Kinyon \& McClure, supra note 167, at 893-97. As its name suggests, reasonable use doctrine picks out and evaluates in detail the use activities of the owners, 2 Waters and Water Rights, supra note $167, \S 10.03$ (b)(3); 5 id. $\S 59.02$ (b)(4); Kinyon \& McClure, supra note 167 , at $904-13$, and so is close to the governance end of the spectrum. In effect, reasonable use assimilates surface water drainage to nuisance law, as is made explicit in Restatement (Second) of Torts $\$ 833$ (1979). Consistent with the information-cost approach, there is a general recognition that replacing the common-law rule of the common enemy (or the civil-law rule of natural flow) with the doctrine of reasonable use takes surface water drainage out of property law and places it in tort law. 5 Waters and Water Rights, supra note $167, \S$ 59.02(a). As expected, exclusion tends to give way to governance as pressure on the resource has increased. Smith, Exclusion versus Governance, supra note 3, at S473$75, \mathrm{~S} 480$. 


\section{Asymmetry and the Rule 4 "Gap"}

Returning to Calabresi and Melamed's four-way typology of rules, the polluter has a package of rights in land that would prevent the pollutee from coming onto the polluter's land to abate the nuisance, and in that sense the rights it has under the ad coelum rule do indirectly protect its activity of polluting in the Rule 3 scenario. But what the polluter does not have is a right "symmetric" to the pollutee's entitlement to be free from pollution in the Rule 1 scenario. It is not as if there are two activities-polluting and preventing pollution-and that Rules 3 and 1, respectively, symmetrically vindicate these use interests. Instead, Rule 1 protects the interest in being free from invasions by pollution, whereas in the Rule 3 situation the "entitlement" to pollute is not a separately delineated right but an undifferentiated privilege. ${ }^{173}$

Thus, when we come to the liability rules (Rules 2 and 4 ) we have to ask what the nature of the entitlement should be. Rule 2 allows the polluter to pollute (to take the victim's entitlement to clean air) as long as the polluter pays officially determined damages, and Rule 4 allows the pollutee to require the polluter to stop polluting as long as the pollutee pays the costs of abating or shutting down. If the entitlement is not symmetric in the case of the property rules (Rules 1 and 3 ), what should we expect in the case of the liability rules? Here it would seem that the liability rule literature, from Calabresi and Melamed onwards, simply (but wrongly) assumes that the use rights really are symmetrical. We have two conflicting uses, for example a feedlot and a retirement community, and the conflict is solved by giving one party a right to stop the other and pay damages-or, under Calabresi and Melamed's formulation, the "entitlement" to do something like emit odors and receive payment from the other for losing this "entitlement."

Why is symmetry important? Besides its contribution to the deductive quality of the derivation of Rule 4, it matters because the lack of symmetry here points to the way entitlements are really delineated in the law. In the property rule case, we are not dealing with Party $A$ with use 1 versus Party $B$ with use 2 and simply decid-

${ }^{173}$ Given the basic exclusion approach based on the ad coelum rule, protection of a true right to pollute would require the additional delineation of an easement. 
ing whether $A$ has a right to engage in use 1 and to stop $B$ from use 2 or vice versa. Instead, $A$ and $B$ each has a right to exclude that implicitly defines a package of use-privileges in a parcel of land, with further fine-tuning of certain specific rights. In this implicit definition of use-privileges, location matters a great deal, as we saw in the nuisance cases. ${ }^{174}$ So in the imaginary scenario where $B$ is using giant fans to ward off pollution, the fact that the fans are on $B$ 's property makes all the difference. If the fans encroached on $A$ 's property or if $B$ went onto $A$ 's land to abate the pollution, then the polluter's actual exclusionary rights do kick in. The important thing is that delineation proceeds around a package of rights in land, not synthetically as a list of use rights as it would on the bundle-ofrights picture of property. Thus, the lack of symmetry between the Rule 1 and Rule 3 cases suggests what is wrong with the way entitlements are conceived in the liability rule literature in the first place.

This misconception about the method of delineating rights suggests why Rule 2 is more common than Rule 4. (I return to the question of Rule 2 damages versus Rule 1 injunctions in Section IV.D.) As we saw with trespass and nuisance, governance rules are sometimes used in high-stakes situations to fine-tune the basic exclusionary regime. But the basic exclusionary regime does not reflect a reciprocal view of causation or a symmetric approach to entitlements. Instead it gives both landowners a right against incursions based on location under the ad coelum rule. When it comes to fine-tuning the basic regime, the governance-style liability rules pegged at particular uses can piggyback on the basic exclusionary set-up. If so, then Rule 2 allows damages for harms that occur on the land, as defined in the rougher exclusionary regime. Basically, Rule 2 , by allowing the polluter to pollute and pay damages, loosens and fine-tunes the basic exclusionary rights that have been delineated in a low-cost way by the ad coelum rule. Rule 2 is still mainly about physical invasions but provides weaker protection than under a trespass-like regime. But Rule 4 goes beyond this: Here the polluter's package of entitlements surrounding its land is not being treated in the same way. Contrary to the assumptions behind Rule 4, the polluter has no right to pollute in the first

\footnotetext{
${ }^{174}$ See supra Part II.
} 
place; the privilege to pollute is simply one of many unspecified privileges it has. If we "supplement" the basic exclusionary package with Rule 4, we are now elevating the privilege to pollute not just to a right but to an individualized stick in a previously undifferentiated bundle.

Why does it matter? Again, the basic exclusion strategy with land as an anchor and proxy variables based on location and entry is a low-cost strategy for owners, courts, and, importantly, for those who have to respect rights. As Merrill and I have argued, the need for third parties to deal with the information about in rem rights helps explain why causation is not treated as reciprocal and why the package of rights in land is a robust one. ${ }^{175}$

The Rule 2 analog, bearing the same relationship as Rule 1 does to Rule 3, would, if such were possible, be a privilege in the polluter protected indirectly by a liability rule protecting the rights against physical invasions by the pollutee. But the pollutee is not physically invading the polluter's land (and any self-help is likely to involve trespass where injunctions are robustly used to protect the exclusionary regime). The Rule 4 "gap" can be explained in terms of information costs: Rule 2 is the needed fine-tuning to a package of rights that centers on land and employs location as its main variable. Versions of Rule 4 do not take advantage of the low-cost exclusionary regime but instead undermine it by transforming an otherwise undifferentiated privilege into a separate right. Thus, like other liability rules but only more so, Rule 4 presents high information costs for courts and potential defendants, and these go a long way toward explaining why we see fewer instances of liability rules, and Rule 4 in particular, than one might expect on the (post)realist view of property generally assumed in law and economics.

\section{DELEgAtion IN TORT AND PROPERTy LAW}

Exclusion permits the law to delegate information gathering and evaluation to owners. Because nuisance law rests on a foundation of exclusion rights with land as a major, salient focal point, the law of nuisance is less like other areas of tort law-such as the law of

175 Merrill \& Smith, What Happened to Property in Law and Economics?, supra note 3 , at 391-94. 
accidents - than theorists expect. In this Part, I will first compare the type of "delegation," decentralization, and information forcing in the information-cost theory with the kinds of delegation advocated in traditional law and economics. I then turn to the difficult question of the scope of the delegation of information gathering to owners: When do changed circumstances, high stakes, and high transaction costs call for judicial solutions to use-conflicts of a more fine-grained, governance type? After identifying the factors relevant to answering this question, I offer reasons to favor an approach based on protecting against physical invasions by means of injunctions with a preference for largely nonjudicial supplementation by governance rules.

\section{A. Exclusion and Delegation in Tort Theory}

Paying attention to how governance supplements exclusion in the law of nuisance allows a different view of "delegation" and "decentralization" in the law of torts. Commentators have long been aware that there is some informational problem lurking in the identification and internalization of externalities. What they have assumed is that all these problems share the same set of informational choices familiar from core areas of tort, such as accident law. Two approaches have received the most attention from commentators. On one, courts can in a direct, "centralized" fashion evaluate activities in terms of their costs and benefits and bring home to the actors engaging in them the costs of those activities to others. ${ }^{176} \mathrm{Di}$ rect balancing is characteristic of the Learned Hand cost-benefit test and various sanctions that prescribe proper behavior based on a cost-benefit test. ${ }^{177}$ Or, on the other approach, courts can proceed in a more "decentralized" way by selecting the cheapest costavoider and placing liability on that actor. ${ }^{178}$ That actor is then

\footnotetext{
${ }^{176}$ See, e.g., Calabresi \& Melamed, supra note 2, at 1092 ("Property rules involve a collective decision as to who is to be given an initial entitlement but not as to the value of the entitlement."); Robert Cooter, Prices and Sanctions, 84 Colum. L. Rev. 1523, 1532-37 (1984) (distinguishing informational requirements for prices and sanctions); Ellickson, Alternatives to Zoning, supra note 114, at 686-87 (distinguishing zoning, nuisance, and covenants as involving decreasing centralization).

${ }^{17}$ See Calabresi \& Hirschoff, supra note 9, at 1056-59 (explaining the Learned Hand test); Cooter, supra note 176, at 1537-38 (analyzing utility of prices and sanctions on the basis of a cost-benefit test); Posner, supra note 7, at 32-33.

${ }^{178}$ See supra notes 9-11 and accompanying text.
} 
delegated the choice between harms and their prevention because the actor will weigh the benefits of the activity against the costs of liability, which are a stand-in for the otherwise external costs. In this cheapest-cost-avoider mode, tort law typically will select out classes of activity for strict liability, for example by announcing ex ante strict liability for all blasting operations rather than determining liability ex post for the particular explosions on an individual construction site. ${ }^{179}$ The strict liability and damages harness information about precaution cost in the possession of the cheapest cost-avoider and delegate the actual, first-order trade-off to that actor.

The exclusion strategy points to a more radical form of decentralization and delegation pervasive in the law of property. Exclusion protects a wide and indefinite range of uses by giving the owner the right to exclude-the gatekeeper right. ${ }^{180}$ The great virtue and the main limitation of this approach is that it does not single out individual uses. The owner can choose among them, and within what the general law allows, can do so without answering to third parties. By contrast, both the direct balancing and cheapestcost-avoider approaches to nuisance require courts to identify and evaluate particular activities. Direct reasonableness inquiries in nuisance are governance rules. Likewise, cheapest-cost-avoider analysis is all about placing liability on certain activities or classes of activities, which requires more individuation and evaluation of activities than does an exclusion regime and a property right. ${ }^{181}$

Moreover, when it comes to nuisance law, the delegation to owners implicit in an exclusion regime allows for a very sweeping ex ante determination. When a dispute arises, a court is called upon to vindicate the already determined exclusion right- not to engage in cost-benefit analysis and a fresh allocation of the entitlement. More tort-like approaches, based on governing activities

\footnotetext{
${ }^{179}$ See Calabresi, supra note 9 , at 146 (discussing the costs of subcategorization); Michelman, supra note 11 , at 656,665 (noting that Calabresi's prospective rules will tend to be framed in terms of broad classes of activities such as driving). But cf. Kaplow \& Shavell, supra note 2, at 719 (arguing that liability rules with damages based on "the average harm for cases characterized by the facts the court observes" will suffice).

${ }^{180}$ See supra note 22 and accompanying text.

${ }^{181}$ Calabresi often uses the locution to place liability on or allocate costs to an "activity," see, for example, Calabresi, supra note 9, at 135, and whether activities or combinations of activities can achieve cost reduction, see, for example, id. at 141, 150.
} 
rather than exclusion from things, envision a more ex post approach. There is a tendency for very detailed judicial doctrines governing use to be standards; ex ante detail is difficult for courts to furnish while deciding one case at a time. ${ }^{182}$ The great virtue of these standards is that they are flexible enough to respond to changing conditions, whereas the rougher approach in a legal regime of exclusion by itself inevitably leads to some overinclusiveness and underinclusiveness. The rough, ex ante regime can be softened, if at all, through (usually standard-like) judicial governance regimes, legislative or administrative schemes, informal norms, or private contracting.

\section{B. The Limits of Exclusion}

On the information-cost view, part of the law of nuisance fulfills precisely this softening function. Nuisance rests on a foundation of exclusion, whether this is labeled trespass or nuisance, but it also fine-tunes this hard-edged regime where the stakes are high enough and courts have some advantage in providing off-the-rack governance rules.

This dual role of nuisance points to one of the most difficult issues facing tort and property law. I have argued that, in a wide variety of contexts, delegation to owners through the exclusion strategy makes sense but has been largely ignored in law and economics, especially in the economic analysis of nuisance law. Sometimes, however, judicial fine-tuning through governance rules is advisable. The question is when to shift from exclusion to governance. This problem presents itself in areas such as easements by necessity, ${ }^{183}$ water

\footnotetext{
${ }^{182}$ Administrative agencies often promulgate very detailed rules. For a comparison of rules and standards, see Louis Kaplow, Rules Versus Standards: An Economic Analysis, 42 Duke L.J. 557, 568-88 (1992).

${ }^{183}$ The familiar doctrine of easements by private necessity in eastern states only applies between parcels that were once united and so governs relations between a grantor and his successors on the one hand and a grantee and his successors on the other, as a default rule in a situation already governed by contract. See, e.g., Goulding v. Cook, 661 N.E.2d 1322, 1325 (Mass. 1996) (holding that a court could not order one landowner to grant another an easement for compensation because this would amount to private eminent domain). On easements by necessity in grantor-grantee situations, see, for example, Hollywyle Ass'n v. Hollister, 324 A.2d 247, 252 (Conn. 1973); 3 R. Powell, Real Property If 410 (1978). In what seems at first blush to be a major departure, doctrines giving nonconsensual access through neighboring private lands by means of easements by necessity for landlocked owners are common in the
} 
law, ${ }^{184}$ the law of caves, ${ }^{185}$ and many others, but perhaps nowhere are the alleged inefficiencies of exclusionary rights and traditional formalistic modes of judicial reasoning in property law more notorious and more often deplored than in the law of oil and gas. Where exactly to draw the line between exclusion and governance is ultimately an empirical question. In this Part, I use the example of oil and gas to suggest that the presumption for exclusion can be fairly strong as long as other institutions generally, and administrative agencies in particular, can be expected to furnish a better governance regime than unilateral court activity.

Before offering some tentative thoughts on what is, after all, primarily an empirical question, it is worthwhile to take stock of what the information-cost theory already provides. The information-cost theory points to a whole class of costs: the information costs in selecting uses, evaluating them, and communicating the rights over them to third parties. By contrast, one reason why the tort approach is so attractive takes us back to Coase. It is very natural to connect externalities with the activities that produce them. If activities become the focus of attention, it is an easy step to assume that the law must regulate activities directly or to assign

western United States; these doctrines arose because of the checkerboard pattern of land disposal by the federal government, and application to officials, hearings, bonds, and compensation are required. See, e.g., Wyo. Stat. Ann. \$§ 24-9-101, 103 (2003); see also Leo Sheep Co. v. United States, 440 U.S. 668, 679-80 (1979) (discussing law of easement by necessity and "private" eminent domain in the western states); Smith, Property and Property Rules, supra note 24.

${ }_{184}$ Interestingly, in terms of the exclusion-versus-governance framework, prior appropriation is further towards the governance end of the spectrum than is usually thought (although not as governance-like as riparianism). Instead, first-appropriation, like the law of oil and gas, focuses on high-visibility actions taken by appropriators and, until recently, did not involve direct measurement of volume. Thus, what Eric Freyfogle identifies as a sensitivity to context in prior-appropriation law makes it more of a governance regime than the conventional story would have it. Compare Eric T. Freyfogle, Context and Accommodation in Modern Property Law, 41 Stan. L. Rev. 1529, 1530 (1989) (arguing that in the law of surface water "[a]utonomous secure property rights have largely given way to use entitlements that are interconnected and relative"), with Terry L. Anderson \& P.J. Hill, The Evolution of Property Rights: A Study of the American West, 18 J.L. \& Econ. 163, 176-78 (1975) (predicting instead "exclusivity" in water law where reserves are scarce). Also, as the demand for precision has increased, water law, like the law of oil and gas, has become largely administrative. On casual surface water in this framework, see supra notes 167-172 and accompanying text.

${ }^{185}$ See infra note 224. 
entitlements over them. If the Coasean, (post)realist approach to nuisance law-with its heavy reliance on liability rules and even Rule 4-style compensated injunctions-focuses on the benefits of what I am calling governance regimes, without a full accounting of their costs, it is no wonder that law and economics has tended to treat nuisance as being all about torts and its regulation of activities, rather than about exclusion and property. Information costs, however, point to a basic and pervasive, but not exclusive, role for exclusion.

The pressing but difficult question is when to shift from exclusion to governance with respect to a given resource-or, more precisely, when to move along the spectrum of informational variables from boundaries to more use-based tailoring. Some cases are not all that difficult. When high-altitude overflights conflicted with strict application of the ad coelum principle that ownership extended indefinitely upward from a parcel of land, courts were ready to define the property rights away from the owner in the face of the enormous transaction costs (and perhaps holdout potential) facing airlines if they had to negotiate with all those owning land lying under the flight path of their airplanes. ${ }^{186}$ Interestingly, one method of doing so was to redefine overflights as falling under the domain of nuisance rather than trespass. Substituting a governance rule for the exclusion approach, these courts held that only flights that actually interfered with the use of the land were actionable. ${ }^{187}$ Nor is the benefit from vindicating the exclusion strategy here very great; as long as planes are flying too high to interfere with existing uses of the land, it is unlikely that losing the right to control the upper airspace defeats any preexisting investments or expectations of the existing owners. But note that the pure balancing approach

\footnotetext{
${ }^{186}$ See, e.g., Brown v. United States, 73 F.3d 1100, 1103-04 (Fed. Cir. 1996); Merrill, supra note 13 , at $36-45$. The Supreme Court has held that deferral statutes have created a public highway at certain minimum altitudes. United States v. Causby, 328 U.S. $256,260-61$ (1946). For a general discussion of the various theories initially used to soften the ad coelum rule in the context of overflights and subsequent statutory developments, see Prosser and Keeton on Torts, supra note 79, $\$ 13$, at 79-82; Colin Cahoon, Low Altitude Airspace: A Property Rights No-Man's Land, 56 J. Air L. \& Com. 157 (1990).

${ }^{187}$ See, e.g., Swetland v. Curtiss Airports Corp., 55 F.2d 201, 203 (6th Cir. 1932); Delta Air Corp. v. Kersey, 20 S.E.2d 245, 249 (Ga. 1942). The First Restatement also created a classic governance regime. Restatement (First) of Torts $§ 194$ (1934).
} 
(on which the more valuable activity wins) might have allowed airlines to escape liability for very valuable low-altitude flights and thereby condemn property near airports without the need for an exercise of eminent domain. ${ }^{188}$

At least in hindsight, we can find examples where strict adherence to the exclusion strategy was probably a mistake. Withdrawal of the delegation to owners and some limited creativity in the (re)definition of property rights would have made sense. But even in these cases, it is often less clear that courts would have been the best innovators in these areas.

\section{Exclusion and its Limits in the Law of Oil and Gas}

A prime - and perhaps the most famous-example of exclusion is oil and gas. Under the exclusionary approach of the common law, withdrawing oil on one's land is one of the large and indefinite class of uses that is indirectly protected by the right to exclude. If this type of use is not curbed, wasteful racing results. But, as is well known, most oil and gas fields involve too many and too heterogeneous a set of participants to allow for private bargaining to an efficient solution such as consensual unitization, under which each owner would take shares in a field under unitary management. ${ }^{189}$

Extending each private owner's exclusion rights in land to the actual stocks of oil would in theory prevent waste, but this approach appeared expensive because the oil was out of sight and

\footnotetext{
${ }^{188}$ Courts have sometimes noted that the denial of an injunction would allow a plaintiff in effect to exercise the power of eminent domain without constraints like the public use requirement. See, e.g., Hulbert v. Cal. Portland Cement Co., 118 P. 928, 930 (Cal. 1911) ("To permit the cement company to continue its operations, even to the extent of destroying the property of the two plaintiffs and requiring payment of the full value thereof, would be, in effect, allowing the seizure of private property for a use other than a public one-something unheard of and totally unauthorized in the law."); Boomer v. Atl. Cement Co., 257 N.E.2d 870, 875, 876-97 (N.Y. 1970) (Jasen, J., dissenting); Arnold v. Melani, 449. P.2d 800, 805 (Wash. 1968) (arguing that the state constitutional provision prohibiting the taking of private property for private use other than for private ways of necessity and so forth does not divest courts of power to refuse injunctions).

${ }^{189}$ See, e.g., Gary D. Libecap, Contracting for Property Rights 95-107 (1989); Gary D. Libecap \& James L. Smith, Regulatory Remedies to the Common Pool: The Limits to Oil Field Unitization, 22 Energy J. 1 (2001); Gary D. Libecap \& James L. Smith, The Self-Enforcing Provisions of Oil and Gas Unit Operating Agreements: Theory and Evidence, 15 J.L. Econ. \& Org. 526 (1999).
} 
moved around in response to drilling activities. It would be difficult to know how much oil, much less whether particular oil, existed under a given parcel. ${ }^{190}$ Given that the United States does not have a regime like that in civil-law countries in which the state owns all minerals in place under both private and public land, early courts faced the problem of clarifying neighbors' rights in oil and gas. In one of the most criticized examples of "formalistic" reasoning, common-law courts analogized oil and gas to other fugitive resources, especially wild animals, and concluded that oil and gas are subject to a "rule of capture." Landowners are privileged to pump and they own any oil they reduce to possession at the surface. Indeed, pragmatist and realist commentators hold up the leading cases drawing the wild-animal analogy as Exhibit $\mathrm{A}$ in their case against "myopic" formalism; look, they say, at how wrong the analogy is and what disastrous results it led to in terms of wasted resources. ${ }^{191}$ To focus on but one example, Richard Posner takes oil and gas as a prime area where judicial pragmatism and attention to contextual detail would have produced superior results to the formalism behind the wild-animal analogy:

${ }^{190}$ See, e.g., Gary D. Libecap \& James L. Smith, The Economic Evolution of Petroleum Property Rights in the United States, 31 J. Legal Stud. S589, S592-93 (2002); Dean Lueck, The Rule of First Possession and the Design of the Law, 38 J.L. \& Econ. 393, 425-26 (1995).

${ }^{191}$ This literature is vast. See, e.g., Bruce M. Kramer \& Patrick H. Martin, The Law of Pooling and Unitization 2-5 (3d ed. 1989); Laura H. Burney, A Pragmatic Approach to Decision Making in the Next Era of Oil and Gas Jurisprudence, 16 J. Energy Nat. Resources \& Envtl. L. 1, 11 (1996) ("To clarify the contours of the pragmatic approach I envision, and to demonstrate its value, I will contrast it to two formalistic approaches used throughout the Great Era. As noted above, by analogizing to the law of wild animals, many early judges myopically adhered to common-law rules rather than venturing to fashion a unique jurisprudence for oil and gas law."); John Parmerlee, Mines and Minerals-Leases-Rentals Accruing Under a Subterranean Gas Storage Lease, 21 U. Kan. City L. Rev. 217, 219-20 (1953) ("If the law pertaining to minerals in this country is to retain its stability and uniformity it is mandatory that this vicious analogy drawn between natural gas and animals ferae naturae which has reared its ugly head be destroyed without delay."); Kenneth J. Vandevelde, The New Property of the Nineteenth Century: The Development of the Modern Concept of Property, 29 Buff. L. Rev. 325, 354-57 (1980). See generally Rance L. Craft, Of Reservoir Hogs and Pelt Fiction: Defending the Ferae Naturae Analogy Between Petroleum and Wildlife, 44 Emory L.J. 697, 699, 713-14 (1995) (documenting hostility and collecting references). 
Armed with the legal rule that there are no nonpossessory rights in wild animals, all you need to know to apply the rule is whether an animal is wild or domesticated. Legal rules economize on information, and that is a good thing. The danger comes when, for example, the rule about nonpossessory rights in wild animals is thought to generalize automatically to a rule that there are no such rights in any nonstationary natural resource. Then we can obtain the 'correct' rule for property rights in oil and gas without having to delve into the economics of developing these resources, all right, but the risk that the resulting regime for oil and gas will be inefficient is very great. The pragmatic approach reverses the sequence. It asks: What is the right rule-the sensible, the socially apt, the reasonable, the efficient rule-for oil and gas? In the course of investigating this question the pragmatist will consult wild-animal law for what (little) light it may throw on the question, but the emphasis will be empirical from the start. ${ }^{192}$

Posner goes on to announce that the "intelligent" answer to whether oil and gas cannot be owned until reduced to possession is "No," and blames the opposite answer-the rule of capture-for impairing incentives to conserve. ${ }^{193}$ Very tellingly, he does not offer any details of how property rights in oil and gas should be delineated. Property casebooks often likewise present oil and gas as a morality tale of the perverse results obtained under formalism and the need for context-sensitive decisionmaking that will respond to society's needs. ${ }^{194}$ On this view, competitive pumping, expensive

\footnotetext{
${ }^{192}$ Richard A. Posner, Overcoming Law 399 (1995).

${ }^{193}$ Id. at 520 .

${ }^{194}$ See, e.g., A. James Casner et al., Cases and Text on Property 44-45 (4th ed. 2000); Charles Donahue, Jr. et al., Cases and Materials on Property: An Introduction to the Concept and the Institution 262 (3d ed. 1993) (noting late development of scientific information about petroleum geology but introducing gas storage by injection case by stating that " $[t]$ he following case, if it does nothing else, illustrates the dangers of carrying arguments by analogy to their illogical conclusion"); Jesse Dukeminier \& James E. Krier, Property 39-40 (5th ed. 2002) [hereinafter Dukeminier \& Krier, Property] (outlining criticisms of "strained analogies" and other problems); Jesse Dukeminier \& James Krier, Teacher's Manual: Property 27 (5th ed. 1998) [hereinafter Dukeminier \& Krier, Teacher's Manual] (criticizing the rule of capture in oil and gas and endorsing judicial suggestions that one landowner might be able to enjoin excessive drilling by another); see also Joseph William Singer, Property Law: Rules and Policies, and Practices $87-89$ (3d ed. 2002) (excerpting critique of rule of capture).
} 
and dangerous surface storage, and so on can be laid at formalism's door.

The information-cost theory calls this gloomy picture into question. Despite the beating that the analogy of oil and gas to wild animals has taken among commentators, it does reflect the fact that the costs of delineating rights to stocks of migratory resources tend to be higher than for stationary ones. ${ }^{195}$ Interestingly, commentary sometimes conflates two traditional approaches to the rule of capture in oil and gas law, each of which is consistent with an exclusion regime. Under the most extreme, unqualified rule of capture, no one has title to oil and gas until it is reduced to possession by extraction. ${ }^{196}$ In the case that often leads this parade of horribles of formalistic reasoning, Hammonds v. Central Kentucky Natural Gas Co., the court used the wild-animal analogy and rule of capture to find that owners of extracted gas lose their property in the gas when they reinject it into a gasless underground formation lying under a neighbor's land. ${ }^{197}$ In Hammonds, the storing company had secured rights to all the 15,000-acre surface over the storage formation except for the fifty-four acres of Della Hammonds, who sued in trespass. ${ }^{198}$ The court found no trespass because the gas was no longer the company's, but this meant that plaintiff Hammonds could have tapped the formation and taken the gas.

Many states, even from the birth of the wild-animal analogy, did recognize property in the oil and gas when it was under an owner's land, but held that the title disappeared as soon as the oil or gas migrated away - even if because of a well drilled by another landowner on his land. ${ }^{199}$ Under this latter, qualified rule of capture, some judicial governance rules of "correlative rights" and "fair share" against the grossest forms of waste can build on the exclusionary regime, in a manner sounding somewhat like the law of

\footnotetext{
${ }^{195}$ See, e.g., Craft, supra note 191, 707-10; Lueck, supra note 190, at 425.

${ }^{196}$ See, e.g., Hammonds v. Cent. Ky. Natural Gas Co., 75 S.W.2d 204, 205 (Ky. 1934), overruled by Tex. Am. Energy Corp. v. Citizens Fidelity Bank \& Trust Co., 736 S.W.2d 25 (Ky. 1987).

${ }^{197} 75$ S.W.2d at 206.

${ }^{198}$ Id. at 204.

${ }^{199}$ The leading case is Westmoreland \& Cambria Natural Gas Co. v. DeWitt, 18 A. 724, 725 (Pa. 1889).
} 
ground water. ${ }^{200}$ These rules do target high-visibility actions such as negligently drilling a well that causes the well to blow out, crater, and catch fire. ${ }^{201}$. Correlative rights include the right against other superincumbent owners engaging in "waste" and "spoilage," but these doctrines only police obvious actions like allowing gas to escape into the air for no legitimate purpose ${ }^{202}$ and leaving unplugged abandoned wells. ${ }^{203}$ Very strikingly, cases that flesh out correlative rights consistently rely on legislative and administrative pronouncements. ${ }^{204}$ Sometimes these judicial doctrines of correlative rights and fair shares have built up around statutes prescribing an equal and just opportunity to extract oil and gas. ${ }^{205}$ As expected, all

${ }^{200}$ See, e.g., 1 Eugene Kuntz, A Treatise on the Law of Oil and Gas $\S 4.3(1987) ; 1$ W.L. Summers, The Law of Oil and Gas $\$ \S 63-65$ (1954). For explicit recognition of the parallels to and differences from the problems of other resources like ground water, see id. $\S 62$, at $164-73, \S 63$, at 184 .

${ }^{201}$ See Elliff v. Texon Drilling Co., 210 S.W.2d 558, 562-63 (Tex. 1948).

${ }^{202}$ See, e.g., Louisville Gas Co. v. Ky. Heating Co., 77 S.W. 368 (Ky. 1903). But cf. Hague v. Wheeler, 27 A. 714, 719 (Pa. 1893) (letting gas escape without malice not enjoinable). See also $1 \mathrm{Kuntz}$, supra note $200, \S 4.4$.

${ }^{203}$ See, e.g., Higgins Oil \& Fuel Co. v. Guar. Oil Co., 82 So. 206, 212 (La. 1919) (spoilage from unplugged abandoned well enjoinable); 1 Kuntz, supra note $200, \S 4.5$, at 123.

${ }^{204}$ Before distinguishing duties arising from purely judicial doctrine and those arising from legislation and regulation, Summers summarizes:

While litigation, apart from statute, has not often arisen in which the courts have had the opportunity to determine a standard of performance of the duty not to injure a source of supply of oil and gas, conservation statutes, defining and prohibiting waste and giving administrative agcncies authority to make and enforce rules for its prevention, do determine such a standard of performance.... A standard of the performance of the duty of a landowner not to take an undue proportion of the oil and gas can only be determined on the basis of scientific information respecting the physical facts of the common source of supply. Usually such information is not available to a landowner in a suit against his neighbor.

1 Summers, supra note $200, \S 63$, at $184-88$. Very interestingly and consistently with the information-cost theory, one case Kuntz cites as a detailed purely judicial rule against excessively quick withdrawal, $1 \mathrm{Kuntz}$, supra note $200, \S 4.5$, at $123 \mathrm{n} .2$, is actually a case about a statute and whether it effects a taking. See Mfrs. Gas \& Oil Co. v. Ind. Natural Gas \& Oil Co., 57 N.E. 912, 917 (Ind. 1900).

${ }^{205}$ See, e.g., Wyo. Stat. Ann. \& 30-5-101(a)(ix) (2003) (defining correlative rights as "the opportunity afforded the owner of each property in a pool to produce, so far as it is reasonably praticable to do so without waste, his just and equitable share of the oil or gas, or both, in the pool"); Anschutz Corp. v. Wyo. Oil \& Gas Conservation Comm'n, 923 P.2d 751, 757 (Wyo. 1996) (quoting this provision); see also Schrimsher Oil \& Gas Exploration v. Stoll, 484 N.E.2d 166, 168 (Ohio Ct. App. 1984) (recognizing statutory modification of rule of capture by creating a new tort). 
the purely judicial doctrines aim at very easy-to-monitor actions, typically occurring at the surface, and do not include any attempt at direct regulation of the quantity of oil removed or the rate of extraction.

On their own, however, these judicial doctrines do not prevent other forms of waste such as drilling too many wells, as long as the wells are not drilled in a negligent manner. ${ }^{206}$ As a leading treatise puts it:

Perhaps most important, it should not be concluded that there is a special correlative rights doctrine which renders the law of capture obsolete, and which is designed to assure to each owner an ascertainable share of the common source of supply to be derived from calculations designed to do complete justice. Correlative rights are complementary to the law of capture in that they provide the refinements required to describe fair play under such law. ${ }^{207}$

As expected on the information-cost theory, a judicial governance regime supplements the basic exclusionary regime, including its privilege of extraction protected by the right to exclude. Where the cost to courts of supplying such governance rules is high, we get a very unambitious governance regime. Thus, when judicial doctrines aim at "waste" in the context of oil and gas, it is, as expected on the information-cost theory, a narrow class of easily monitored waste.

Furthermore, the qualified rule of capture forms the foundation for rules of governance by administrative bodies, which can claim to be operating consistently with all owners' exclusion rights. Indeed, perhaps the most important contribution of the correlative rights doctrine, if any, is not that it involved courts in supervising (a highly limited class of) wasteful activities. Rather, it is that it may have eased the way for legislatures and administrative agencies (such as the Texas Railroad Commission) to intervene, without

${ }^{206} 1 \mathrm{Kuntz}$, supra note $200, \S 4.2 ; 1$ Patrick H. Martin \& Bruce M. Kramer, Williams \& Meyers on Oil and Gas Law § 204.4 (1997); 1 Summers, supra note 200, §§ 61-65; Thomas M. Golden, Secondary Recovery Operations-Protection of Correlative Rights, 2 Land \& Water L. Rev. 129, 141 (1967) (noting that the right to a fair share "does not assure a proportionate share of the minerals; it simply means that he has a right to a fair opportunity to extract oil and gas") (citing 1 Kuntz, supra note 200 , §§ $4.1,4.2,4.7)$.

${ }^{207} 1 \mathrm{Kuntz}$, supra note $200, \S 4.3$, at $120-21$. 
having to worry about takings claims. Under the correlative rights doctrine, surface owners did have property in oil and gas underground, and such statutes can be regarded as securing the property rights of all the owners. ${ }^{208}$ These legislative and administrative measures aimed at preventing both injury to the common pool and landowners from taking an undue proportion of the resource. ${ }^{209}$ These measures included well-spacing rules, regulations about rates of extraction, and detailed rules about drilling and extraction procedures, as well as legislative schemes for forced unitization. ${ }^{210}$ Most statutes give an administrative authority over the governance regime, ${ }^{211}$ and these regimes regulate far more than the gross waste that purely judicial doctrines targeted.

Legislation did not necessarily reflect a failure of courts to "get it right." In light of their greater expertise and ability to deal with the problem on a field-wide basis, these statutory and administrative schemes are probably more successful than a judicial conservation governance regime could have been. Judicial attempts to implement a more comprehensive governance regime might well have taken the pressure off other bodies to do something about the problem. Furthermore, when comparing institutions' abilities in devising governance regimes, the rule of capture looks better when we realize that nothing in the courts' traditional approach-the ad coelum rule or the analogy of oil and gas to wild animalsprevented a court from upholding these legislative and administrative measures as exercises of the police power. ${ }^{212}$ As we will see shortly, even the formalistic approach of Hammonds did not preclude legislatures from solving the underground storage problem through condemnation statutes, without running afoul of publicuse requirements. While it is also true that the legislative and administrative schemes put in place were far from perfect, perfection cannot be the proper standard. Those criticizing the courts for failing to apply scientific expertise and blaming formalistic exclusion-

${ }^{208}$ Ohio Oil Co. v. Indiana, 177 U.S. 190, 209-10 (1900); Schrimsher Oil, 484 N.E.2d at 168 .

${ }^{209} 1$ Summers, supra note $200, \S 63$, at $183-84$.

${ }^{210}$ See id. $\$ \S 71-98$; Martin \& Kramer, supra note 206, § 5.01.

${ }^{211}$ See 1 Summers, supra note 200, $\$ 71$, at 198. 69.

${ }^{212}$ Indeed, most courts did uphold these policy measures. See, e.g., id. § 62, at 167- 
based analogical reasoning for the failures of oil and gas law have not presented reasons to think that a judicial governance scheme would have been more successful, or cheaper, than the imperfect mixed judicial-legislative-administrative regime that actually developed.

As I have noted, the Hammonds decision, which applied a pure rule of capture and a very strict approach to the ad coelum rule, has been roundly condemned as an example of wrongheaded formalistic reasoning leading to economic waste. ${ }^{213}$ Many commentators have struggled with the Hammonds problem of underground storage, and a variety of judicial solutions-along the lines of airplane overflights-have been suggested in which the property rights over the storage would be defined away from owners of the surface land. ${ }^{214} \mathrm{By}$ contrast to the correct approach in airplane overflights, it is said, decisions like Hammonds prevented economic storage of natural gas. ${ }^{215}$ But it should be noted that these solutions are not as easy to implement in the case of underground gas storage because, unlike with the distant sky, owners may well find a use of the underground space taken by the stored gas. ${ }^{216}$

The commentators' dire claims regarding Hammonds are at best overstated. Whether courts followed the Hammonds unqualified rule of capture or the qualified rule of capture, the result was to place the problem of economic storage of natural gas in a different

${ }^{213}$ See, e.g., Lone Star Gas Co. v. Murchison, 353 S.W.2d 870, 876-77, 879 (Tex. Civ. App. 1962) (rejecting Hammonds and documenting that "Hammonds, in its application of ferae naturae doctrine, has been the subject of violent adverse criticism by many authors and law review writers"); Burney, supra note 191, at 22-26.

${ }^{214}$ See, e.g., Note, The Ownership of Natural Gas and Some Real Property Concepts, 36 Va. L. Rev. 947, 954 (1950) (claiming to apply Pollock's doctrine of possible effective possession, see Frederick Pollock \& Robert Samuel Wright, An Essay on Possession in the Common Law (Oxford, Clarendon Press 1888)). The implication in much of the critique of the rule of capture is that a more elaborate judicial doctrine of reasonable use or correlative rights would be best. This type of commentary does not inquire into the difficulties of courts supervising such a rule.

${ }^{2 t s}$ See, e.g., Charles Donahue, Jr., Thomas E. Kauper, \& Peter W. Martin, Teacher's Manual to Accompany Property: An Introduction to the Concept and the Institution 66-67 (3d ed. 1993); Dukeminier \& Krier, Property, supra note 194, at 39 ("There is a reason independent of strained analogies to discard the rule in Hammonds: It denied society at large the benefits of economical underground storage.").

${ }^{215}$ See infra note 221 and accompanying text. 
arena. ${ }^{217}$ Private parties negotiated for storage where holdouts were not preclusive, and many states passed condemnation statutes. ${ }^{218}$ The condemnation statutes, as well as the spacing, pumping, and unitization regulations, are detailed and comprehensive in a way that would have been difficult for judges to achieve through rules of decision. Judges cooperated in finding that these condemnation statutes did not violate the relevant public-use requirements for an exercise of eminent domain. ${ }^{219}$ Even the much-maligned Kentucky Supreme Court, the originator of the most extreme rule of capture decision in Hammonds, found a storage condemnation statute constitutional in Cornwell v. Central Kentucky Natural Gas, thus allowing a solution to the holdout problem. ${ }^{220}$ The provisions about and the market rents paid for storage and rights to apparently depleted strata reflect the view that they are not worthless or de minimis. ${ }^{221}$ In particular, surface owners or their mineral grantees (or lessees) may have an interest in developing strata below the storage stratum. Reconciling these multiple uses requires a more context sensitive governance regime, which both condemnation statutes and privately negotiated divisions of rights furnish. It is far from clear that a pragmatic judge, seeking the optimal solution, would have even addressed this part of the problem, and the various "solutions" to the Hammonds problem by commentators do not give grounds for optimism. Eminent domain, with compensation and various procedural safeguards, is superior to judicial "redefinitions" of property rights that allow gas storage companies to inject gas with no liability at all, as well as to protecting a landowner with only a liability rule. ${ }^{222}$

${ }^{217}$ See Alan Stamm, Legal Problems in the Underground Storage of Natural Gas, 36 Tex. L. Rev. 161 (1957).

${ }^{218}$ See, e.g., Stamm, supra note 217 , at $174-84$.

${ }^{219} \mathrm{Id}$.

${ }^{220} 249$ S.W.2d 531 (Ky. 1952).

${ }^{221}$ See, e.g., Stamm, supra note 217 , at 172-74 (examining storage provisions in leases). One reason for treating "apparently" exhausted strata as valuable is that they may contain native oil or gas that will become economically extractable at a later date. Id. at 168; Note, Oil and Gas: Substratum Storage Problems, 7 Okla. L. Rev. 225, 227 (1954) (citing Engineering Committee, Interstate Oil Compact Commission, Oil and Gas Production 47-50 (1951)).

${ }^{222}$ See supra notes 58-61 and accompanying text; see also Smith, Property and Property Rules, supra note 24 . 
Judicial policing of certain actions like burning off oil can be observed by courts and subjected to governance rules, but detailed rules relating to the rate of extraction are likely to be more difficult for courts to devise and monitor than in the cases of water and wild animals. The point is not so much that the analogy to water or wildlife does not solve the problem of waste, but rather what type and degree of judicial softening of the exclusion regime is appropriate, given that legislatures and administrative agencies are in a much better position to address the problem technically, if not politically (or even militarily). ${ }^{223}$ Perhaps it is more important in case of the discovery of a new dimension to a resource to use the exclusion regime in a way that does not preclude or delay legislative and administrative efforts to devise governance regimes. ${ }^{224}$ Whether courts should get more involved in devising governance rules in light of the difficult public-choice dynamics of regulating oil and gas extraction is a tough question, particularly at the (early) time a rule is called for. ${ }^{225}$ Given the high delineation costs of oil and gas,

${ }^{223}$ See Craft, supra note 191, at 718-21 (arguing that courts did not have the authority or capacity to provide a better rule than the rule of capture such as those later developed in the administrative context). As Libecap and Wiggins document, when ownership of oil was very dispersed (with an inverse of the Herfindahl index of greater than around 10-12), enforcement of limits on extraction required the use of troops. Gary D. Libecap \& Steven N. Wiggins, Contractual Responses to the Common Pool: Prorationing of Crude Oil Production, 74 Am. Econ. Rev. 87, 96 (1984).

${ }^{224}$ Another possible example comes from the law of cave ownership, a problem Coase noted in a discussion foreshadowing what would come to be known as the Coase Theorem. R.H. Coase, The Federal Communications Commission, 2 J.L. \& Econ. 1, 25 (1959). In the leading but much-criticized decision in Edwards v. Sims (authored by none other than Commissioner Stanley, who wrote the opinion in Hammonds), ownership of the Great Onyx Cave, a potential tourist site, was held to be in the surface owners, according to the ad coelum rule. 24 S.W.2d 619, 621 (Ky. 1929). After much litigation, the state exercised its power of eminent domain and operated the cave itself. Edwards v. Lee's Adm'r, 96 S.W.2d 1028, 1029 (Ky. 1936). Arguing in favor of departing in this context from the ad inferos part of the ad coelum rule (as by holding that the owner of the mouth gets the cave), Richard Epstein estimates that the problem of holdout is great and the likely externality (for example, from mining by the non-cave-owning surface owner) is small. See Epstein, Holdouts, supra note 78 , at $563-67$.

${ }^{225}$ This question turns in part on how subject to capture legislatures and courts are and how to define capture in the first place. See, e.g., Einer R. Elhauge, Does Interest Group Theory Justify More Intrusive Judicial Review?, 101 Yale L.J. 31 (1991); William N. Eskridge, Jr., Politics Without Romance: Implications of Public Choice Theory for Statutory Interpretation, 74 Va. L. Rev. 275, 285 (1988). 
the limited rule of capture with governance rules prohibiting gross waste is defensible if supplemented by public regulation.

\section{The Limits of Injunctive Relief}

In another common situation that commentators usually treat as calling for a softening of the exclusion regime-this time through replacing traditional injunctions with damage awards-the defendant's industrial use is thought to be more valuable and the plaintiffs so numerous and uncoordinated as to present an overriding danger of high transaction costs and holdout behavior in particular.

The formative period of nuisance law in the nineteenth century witnessed a concern for maintaining the exclusionary aspect of property even where rich and powerful industrial interests no doubt would have preferred weaker forms of protection. ${ }^{226}$ Interestingly, the traditional strong protection of property through the exclusionary aspect of nuisance was remarkably robust in the face of claims that it might retard economic development. ${ }^{227}$ It is only more recently that concerns about shutting down plants have come to be

${ }^{226}$ Courts occasionally made statements to this effect:

Although the damage to the plaintiff may be slight as compared with the defendant's expense of abating the condition, that is not a good reason for refusing an injunction. Neither courts of equity nor law can be guided by such a rule, for if followed to its logical conclusion it would deprive the poor litigant of his little property by giving it to those already rich. It is always to be remembered in such cases that "denying the injunction puts the hardship on the party in whose favor the legal right exists, instead of on the wrongdoer."

Whalen v. Union Bag \& Paper Co., 101 N.E. 805, 806 (N.Y. 1913) (quoting 5 Pomeroy's Equitable Jurisprudence $\S 530$ (San Francisco, Bancroft-Whitney 188687)).

A.W.B. Simpson, Leading Cases in the Common Law 163-94 (1995) (discussing Tipping v. St. Helen's Smelting Co., 4 B. \& S. 608, 616, 122 E.R. 588, 591, 11 H.L.C. 642, 11 E.R. 1483, 1 Ch. App. Cas. 66 (1865)). The thesis that nineteenth-century tort law softened liability for business as a "subsidy" has come into serious question. Compare Lawrence M. Friedman, A History of American Law 475 (2d ed. 1985), and Morton Horwitz, The Transformation of American Law, 1780-1860, at 85-89 (1977), with Simpson, supra, at 191-94 (discussing victory of a wealthy landowner in a nuisance case against an industrial polluter but expressing skepticism that English nuisance law had much effect on pollution or the pace of industrialization), Gary $T$. Schwartz, The Character of Early American Tort Law, 36 UCLA L. Rev. 641, 642-43 (1989) (arguing that courts in the nineteenth century were generous in upholding tort liability against defendants in emerging industry), Gary T. Schwartz, Tort Law and the Economy in Nineteenth-Century America: A Reinterpretation, 90 Yale L.J. 1717, 1735-58 (1981) (critiquing the subsidy thesis). 
widely viewed as trumping strong property protection for residents. $^{228}$

The now classic example of this situation and of the modern loosening approach is the case of Boomer v. Atlantic Cement Co. ${ }^{229}$ In that case, a cement plant caused pollution that disturbed neighboring landowners. Traditionally New York law would have almost automatically awarded the plaintiffs an injunction on these facts. ${ }^{230}$ The fear was that the large number of plaintiffs would present high transaction costs, especially holdout problems, that would make bargaining around an injunction impossible. ${ }^{231}$ If so, the result of an injunction would be to force the plant to shut down. In Boomer, the trial court found a substantial nuisance but refused to grant an injunction and the Court of Appeals affirmed. ${ }^{232}$ In upholding the refusal of the injunction, the court was softening the exclusion regime to capture value that a crude exclusion regime apparently could not.

Interestingly, this cautionary tale of high transaction costs seems less straightforward than it once did. First, the disturbance to the

${ }^{228}$ Louise Halper has argued that damages remedies were not as unprecedented in pre-Boomer New York nuisance law as the conventional view holds. See Louise A. Halper, Nuisance, Courts and Markets in the New York Court of Appeals, 1850-1915, 54 Alb. L. Rev. 301, 303-06 (1990); cf. Joel C. Dobris, Boomer Twenty Years Later: An Introduction, with Some Footnotes about "Theory," 54 Alb. L. Rev. 171, 179 (1990) (arguing that Boomer was a watershed in applying balance of the equities to the issue of injunctions in New York nuisance law). Halper emphasizes what I would call the governance component of nuisance law. See Halper, supra, at 349-54; see also Carol M. Rose, The Several Futures of Property: Of Cyberspace and Folk Tales, Emission Trades and Ecosystems, 83 Minn. L. Rev. 129, 179 (1998) (arguing that turnof-the-century nuisance law specified a commons much like that in riparianism in water law).

${ }^{229} 257$ N.E.2d 870 (N.Y. 1970).

${ }^{230}$ See, e.g., Whalen v. Union Bag \& Paper Co., 101 N.E. 805 (N.Y. 1913) (reversing the Appellate Division's reversal of a grant of an injunction where the plaintiff's harm was $\$ 100$ a year and the value of the offending paper mill was more than $\$ 1,000,000$, with 400 to 500 employees).

${ }^{231}$ See, e.g., Robert Cooter \& Thomas Ulen, Law and Economics 170-80 (1988); Richard A. Posner, Economic Analysis of Law 16, 68-71, 79-81 (5th ed. 1998); Calabresi \& Melamed, supra note 2, at 1106-10; Robert Cooter, Unity in Tort, Contract, and Property: The Model of Precaution, 73 Cal. L. Rev. 1, 26-27 (1985); A. Mitchell Polinsky, Controlling Externalities and Protecting Entitlements: Property Rights, Liability Rule, and Tax-Subsidy Approaches, 8 J. Legal Stud. 1, 4 (1979); A. Mitchell Polinsky, Resolving Nuisance Disputes: The Simple Economics of Injunctive and Damage Remedies, 32 Stan. L. Rev. 1075, 1076 (1980).

232257 N.E.2d at 875. 
nearest neighbors was far greater than the Court of Appeals decision indicated. ${ }^{233}$ On the other hand, the permanent damages for the nuisance (in a sense the purchase price for an easement) awarded on remand were much higher than the apparent diminution in fair market value that the court suggested as the standard. ${ }^{234}$ Furthermore, as some authors have pointed out, it is not at all clear that Atlantic Cement had no alternatives ex ante. Possibilities might include assembling a larger tract for the plant, ${ }^{235}$ acquiring the tract it did acquire but negotiating for easements, or finding another site altogether. To this we can add that under the loose approach to the public use requirement in federal and much state takings law, companies like Atlantic will sometimes be able to condemn the desired tract. ${ }^{236}$

Despite these considerations, one might-as many do-argue that in high-transaction-cost situations with potential holding out and other strategic behavior, the exclusion strategy has been carried too far in the past and that a little realist innovation on the part of judges would have helped. Although each of these situations looks like an obvious case for softening the exclusionary regime, a wider view of what the defendant could have done ex ante and which other institutions might have dealt with the holdout

${ }^{233}$ See Daniel A. Farber, Reassessing Boomer: Justice, Efficiency, and Nuisance Law, in Property Law and Legal Education: Essays in Honor of John E. Cribbet 7, 78 (Peter Hay \& Michael H. Hoeflich eds., 1988).

${ }_{234}$ Id. at 11-12 (noting that after remand Atlantic Cement's total liability came to around four times the amount mentioned in the Court of Appeals decision).

${ }^{235}$ This possibility was noted by Lord Justice Thesiger in Sturges v. Bridgman, $11 \mathrm{Ch}$. D. 852, 865 (1879) (Eng.) ("The smith in the case supposed [a nuisance causing the defendant harm] might protect himself by taking a sufficient curtilage to ensure what he does from being at any time an annoyance to his neighbor ....").

${ }^{236}$ The leading case of a weak public use requirement in the federal Takings Clause in the face of government use of eminent domain followed by transfer to private parties is Hawaii Housing Authority v. Midkiff, 467 U.S. 229 (1984), which upheld a transfer title from landlords to tenants upon payment of compensation as furthering public purpose of reducing concentration of land ownership. On the approaches of various states and how acquisition for transfer has been held consistent with state public use requirements, see David A. Dana \& Thomas W. Merrill, Property: Takings 207-08, 207 n.323 (2002) (discussing and citing cases). In New York, the state in which the Boomer case arose, a court has upheld the use of eminent domain to assemble a parcel for a private shopping center because it would "reduce urban physical and economic blight and promote economic revitalization of the acquisition site." Sun Co. v. City of Syracuse Indus. Dev. Agency, 625 N.Y.S.2d 371, 377 (N.Y. App. Div. 1995). 
problem makes the case for expansion of judicial governance a tentative one at best.

Two qualifications to the need for more judicial governance are in order. First, the exclusion strategy may be "working" even if we can point in retrospect to places where it did not lead to ideal results. To avoid the nirvana fallacy of comparing an actual system with an idealized alternative, we must compare the feasible alternatives. $^{237}$ The question is how strong a presumption for delegation through the exclusion rules gives the best result in the long run, not in any given situation. If we stick with exclusion come what may, obvious problems like the waste of the common-law rules applied to oil and gas would become commonplace-so commonplace that some judicial fine-tuning through governance rules might make sense. The strictest approach to exclusion would have prevented the law of nuisance from ever having developed in the first place. At the opposite extreme, if courts afford no weight to the presumption for exclusion, then owners and takers would know that the delegation is meaningless. Under the weakest presumption for exclusion, courts can be forced to evaluate uses even where owners and takers have an advantage in doing so.

If a presumption of decentralization and delegation to owners is valuable for reasons of information costs, as I have argued, the question then becomes: How high do the stakes have to be and how dire do transaction costs or holdout problems have to become for it to make sense for the law to engage in the type of fine-tuning through governance rules that the law-and-economics literature assumes should be routine? The simple answer to this question is that we do not have the empirical data to give an exact or even remotely certain answer. But we do have some information. Again, exclusion is ubiquitous in customary systems where many of the costs of creating the exclusion rules are largely internalized to the producers of the institution. This suggests that exclusion makes sense in a wide range of situations. ${ }^{238}$ Likewise, the widespread,

${ }^{237}$ Harold Demsetz, Information and Efficiency: Another Viewpoint, 12 J.L. \& Econ. 1, 1-4 (1969) (identifying and discussing the nirvana fallacy).

${ }^{238}$ Robert Ellickson has hypothesized that institutions worked out by members of close-knit communities are wealth-maximizing for the group. Ellickson, Order without Law, supra note 65, at 167-84; Ellickson, Property in Land, supra note 46, at 1320-21. If so, then the widespread use of exclusion among such groups is a positive 
though often unacknowledged, use of exclusion in ours and other legal systems suggests that exclusion has some rationale and should not be dismissed lightly. ${ }^{239}$ Also, the more difficult that uses are to separate or to evaluate the more we should expect exclusion.

Thus, even as a rough guess, the presumption for exclusion should be higher than current commentary and the Restatement would have it. Treating the resource conflicts among neighboring landowners as immediately calling for reasonableness inquiries, balancing of utilities, and denials of injunctions gives too little weight to the information-cost advantage of exclusion-not to mention the values of liberty and personhood that groups like residential homeowners enjoy under a strong property regime.

The question is when holdout problems become so great as to overcome the presumption built into the exclusion regime. The Boomer approach deals with the situation after the plant is built. At this stage there is no question that there would be high transaction costs and holdouts if injunctions were used. Is an ex ante perspective possible on the Boomer approach? The relevant question is the holdout potential and difficulty of assembling a large enough parcel before the factory is built (or expanded). In the face of an existing factory that might have to shut down in the absence of bargaining around an injunction, the tendency will be to sympathize with the problems involved in land assembly. Although it is true that purchases disguised through agents and other such devices are costly, so is removing property rule protection from other landowners. Moreover, at the time of assembly one would want to ask whether the site involving the homeowners is the most suitable site and how much more suitable it is than the next best site. Only in the case of industrial operations that need to be located near a source of raw materials, a waterway, or some other facility will these considerations point towards a need to loosen property rule protection for those already owning land in the area.

\footnotetext{
sign. Notice that Ellickson does not claim that the norms and institutions of close-knit groups are necessarily wealth-maximizing for a wider set of people. Ellickson, Order without Law, supra note 65, at 169; Ellickson, Property in Land, supra note 46, at 1400.

${ }^{239}$ See, e.g., Epstein, A Clear View, supra note 146; Smith, Property and Property Rules, supra note 24 .
} 
These ex ante considerations are difficult to consider on the Boomer liability-rule approach. Because in a nuisance action the plant is already built, ex ante considerations will be difficult to prove and to act on even if proved. (A court will be reluctant to shut down a plant even if the landowners can point to an alternative site that could have been chosen.) Some kind of safety valve from a strict exclusion-based approach may be necessary because courts may not stick with bright-line exclusionary rules. As Robert Ellickson argues, one response of courts to rules requiring injunctions even in the face of massive hardship is to manipulate the findings of liability. Given a choice between finding a nuisance with an automatic injunction and finding no nuisance, courts may opt for the latter, leaving plaintiffs without even a damage remedy. ${ }^{240}$ In general, the traditional rule that equity abhors forfeitures accommodated this tendency. ${ }^{241}$ Courts find it hard to resist trying to avoid unfairness or waste ex post when faced by a concrete problem. As Carol Rose points out, this is one reason that "crystal" or bright-line rules come to be "muddy" after judges make exceptions and introduce balancing tests in order to save unfortunate and ignorant parties from harsh results. ${ }^{242}$

In the past, the law has favored legislative schemes tailored to the "unique" resource problem as a very limited safety valve for the Boomer problem. Thus, the famous Mill Acts ${ }^{243}$ and Western

${ }^{240}$ See Ellickson, Alternatives to Zoning, supra note 114 , at 720 . As a prime example, Ellickson cites and discusses Bove v. Donner-Hanna Coke Corp., 258 N.Y.S. 229, 233-36 (N.Y. App. Div. 1932), in which the nuisance from the defendant's plant was severe, and if recognized would have led to automatic availability of an injunction shutting the plant down. The court avoided finding nuisance by wrongly invoking coming to the nuisance and permissive zoning.

${ }^{241}$ See, e.g., Roger A. Cunningham et al., The Law of Property $\$ 6.76$ (1984). Sometimes courts announce that this maxim is to be applied with caution, lest it destroy established rights. See, e.g., Dunkin' Donuts v. Middletown Donut Corp., 495 A.2d 66 (N.J. 1985).

${ }^{242}$ Carol M. Rose, Crystals and Mud in Property Law, 40 Stan. L. Rev. 577, 601-04 (1988). In passing, Rose notes that "nuisance is one of those extraordinarily shapeless doctrinal areas in the law of property," id. at 579, although I would argue that nuisance is a complex blend of exclusion crystal and muddy governance.

${ }^{243}$ See, e.g., New Hampshire Mill Act, 1868 N.H. Laws ch. 20, § 3; see Head v. Amoskeag Mfg. Co., 113 U.S. 9, 10-11 (1885) (quoting and discussing the act); Epstein, A Clear View, supra note 146, at 2114; see also John F. Hart, The Maryland Mill Act, 1669-1766: Economic Policy and the Confiscatory Redistribution of Private 
easement-by-necessity statutes ${ }^{24}$ are tailored to situations in which ex ante the one proposing the new use has limited options in who to deal with. Possible mill sites are limited in number as are potential servient plots over which easements for landlocked and waterless plots might be located. Furthermore, these schemes require the one proposing to condemn rights to justify the condemnation as consistent with the public interest, in a manner at least as stringent as that required in exercises of eminent domain. ${ }^{245}$ The potential condemnees have a chance to object and to introduce evidence about alternatives, because the would-be condemnor cannot present the world with a fait accompli. By refusing a blanket after-thefact Boomer-style liability rule approach and requiring such ex ante safeguards in any legislative solutions to the holdout and transaction-cost problems involved in unique siting situations, one can solve the most compelling concerns motivating the Boomer approach with minimal impact on the basic exclusionary regime.

In the nuisance area, it is not clear that the safety valve has to be all that large in order to capture most of its benefits, for two reasons. First, as long as actors like Atlantic Cement in Boomer know that they will most likely face injunction for nuisances, the factory owner can sometimes buy up more land in the neighborhood before building the plant, especially if it uses an agent who maintains secrecy about the principal's identity and plans. ${ }^{246}$ Second, promot-

Property, 39 Am. J. Legal Hist. 1, 3-5 (1995) (comparing the Maryland Mill Act with a Virginia statute meant to encourage the erection of mills).

${ }^{244}$ See, e.g., Wyo. Stat. Ann. $\$ \$ 24-9-101$ to -103 (2003); Leo Sheep Co. v. United States, 440 U.S. 668, 680 (1979) (discussing law of easement by necessity and "private" eminent domain in the western states).

${ }^{245}$ See, e.g., Epstein, A Clear View, supra note 146, at 2111-20; Smith, Property and Property Rules, supra note 24; see also Thomas W. Merrill, The Economics of Public Use, 72 Cornell L. Rev. 61, 81 (1986) (noting how cumbersomeness of eminent domain acts as a "due process tax" on exercises of the power).

${ }^{246}$ Although many economists have often expressed theoretical worries about the high transaction costs of land assembly using market transactions, the case for eminent domain as a device for lowering transaction costs is tenuous. See Robert C. Ellickson \& Vicki L. Been, Land Use Controls: Cases and Materials 1029-40 (2d ed. 2000) (discussing how private firms assembling land deal with holdouts by various methods, including secrecy, threats to build around, offers conditional on all landowners accepting, and other more colorful methods); Patricia Munch, An Economic Analysis of Eminent Domain, 84 J. Pol. Econ. 473 (1976) (presenting a theoretical model of land assembly under eminent domain and voluntary transactions and pro- 
ing bargaining ex ante also avoids the problems of rancor that beset negotiations ex post. ${ }^{247}$

The information-cost theory suggests that a legislative scheme of compensation with a variety of procedural safeguards is superior to a judicial expansion of liability rules. Aside from questions about whether courts or agencies are better at setting compensation for pollutees, judicial liability rules destabilize expectations under property regimes by allowing the polluter to initiate a nonconsensual transaction with no warning, and with no need to justify itself to the public. Although the provisions for bonds, hearings, and so on, under schemes like the Mill Acts and Western easement-bynecessity statutes are surely imperfect, they do place some obstacles in the way of the opportunistic use of liability rules. Perhaps more importantly, if the information-cost theory is correct, an entitlement scheme is undermined by each new application of the liability rule approach. Where the limited number of such innovations should be applied requires a comprehensive view that is very difficult for courts to take. As is generally the case, legislatures are institutionally superior to courts in revising the structure of entitlements. ${ }^{248}$

Nuisance is not the only, nor the most effective, method of land use control, and nuisance plays only a small part in controlling air pollution. ${ }^{249}$ The existence of these other methods takes some of the pressure off nuisance and allows it to be simpler and more exclu-

viding empirical study of urban renewal in Chicago suggesting that assembly by consensual transactions is more efficient than by forced sales).

${ }^{247}$ In a suggestive study of twenty nuisance cases resulting in a "property rule" result (injunction or no liability) litigated to the written appellate decision stage, Ward Farnsworth found that no set of parties bargained around the result. Ward Farnsworth, Do Parties to Nuisance Cases Bargain After Judgment? A Glimpse Inside the Cathedral, 66 U. Chi. L. Rev. 373 (1999). The lawyers interviewed attributed the lack of trades to enmity, which is probably more likely in cases that have been litigated to an appellate decision than in the total universe of nuisance disputes.

${ }^{248}$ For an extended argument to this effect in the context of the numerus clausus principle, see Merrill \& Smith, Optimal Standardization in the Law of Property, supra note 28 , at $58-68$.

${ }^{249}$ See Boomer v. Atlantic Cement Co., 257 N.E.2d 870, 871 (N.Y. 1970); Dukeminier \& Krier, Teacher's Manual, supra note 194, at 822; Martin H. Belsky, Environmental Policy Law in the 1980's: Shifting Back the Burden of Proof, 12 Ecology L.Q. 1, 6-10, 13-14 (1984); Rose, Rethinking Environmental Controls, supra note 35, at 25-26. 
sionary. ${ }^{250}$ Although some judicial relaxation of the ad coelum rule makes sense, given the abilities of private parties sometimes to bargain ex ante and the general superiority of legislatures and agencies to courts in supplying detail and providing implicit compensation, small shifts by courts from exclusion to governance go a long way. What the best-and politically feasible-mix of controls is out of a set that includes not only nuisance but covenants, zoning, and pollution regulation, is beyond the scope of this Article. When greater precision of use rights is valuable, we may expect some tendency to shift along the spectrum from exclusion to governance but this may take the form of movement from courts to some other institution or to private parties.

Thus, the problem in Boomer is to determine when high transaction costs and potential holdouts make it advantageous to back off the exclusionary regime somewhat and split the entitlement between the homeowners and the polluter. The big mistake in the majority's opinion in Boomer is to take this problem as calling immediately for reasonableness balancing of the costs and benefits of activities, under an elaborate judicial governance regime. One alternative view of the Boomer problem is that it is really a very narrow one relating to nearly "unique" sites, a problem best solved, as it has been in the past, with tailored legislative condemnation schemes characterized by up-front procedural safeguards. If, as the information-cost theory suggests, the delegation of use-determinations to owners has some presumptive value, limiting the departures from it in the direction of governance makes sense, and these departures will often best be supplied legislatively or administratively, if not through private transacting.

\section{CONCLUSION}

Nuisance law is a window onto the impact of information costs on the law. Contrary to a growing conventional wisdom, nuisance law is not simply a tort-like regulation of activities projected onto a

\footnotetext{
${ }^{250} \mathrm{Cf}$. Merrill, supra note 13 , at 46 (suggesting that a very judgmental regime of public nuisance could allow private nuisance law to be more bright line). Recognizing the same relationship, Ellickson conversely argues that improvements to nuisance doctrine would allow nuisance to take back some of the domain it has ceded to other forms of land-use control. See Ellickson, Alternatives to Zoning, supra note 114, at
} 722. 
backdrop of land ownership. Nor is nuisance just like trespass, which is for the most part based on simple signals like boundary crossings and on rights to exclude, but again it is easy to forget how much of nuisance still does resemble the law of trespass. In this Article I have argued that nuisance shares features of both torts and regulation on the one hand and core property and trespass on the other. In the terms of this Article, nuisance carries forward the basic exclusion strategy based on the ad coelum rule from trespass and supplements-but does not supplant-this exclusion regime with governance rules of a more tort-like sort.

Exclusion and governance, and the various strategies in between, have their own characteristic sets of costs and benefits, and it is these that help explain and justify the complex hybrid of rules in the law of nuisance. Exclusion is low cost but low precision and makes sense where the benefits of tailoring-in terms of specialized multiple use of a resource-are at their weakest and where the benefits of delegation to owners are strongest. Exclusion allows third parties like legislatures, courts, and officials to limit themselves to second-order questions of who is the best chooser on a first-order level among the uses to which resources can be put. As a first approximation, owners can choose among a large and indefinite set of uses of land without having to justify or even articulate the hunches and values upon which those decisions rest. Furthermore, these simple rules of exclusion are easy to communicate to third parties, who can mostly contribute to the value of a resource by keeping off. The ease with which both third-party enforcers and third-party dutyholders can deal with exclusion makes it an attractive one to choose, and this choice has been made at many times and places both as a matter of custom and of law, and in groups both close-knit and impersonal. It is so basic that it is easy to overlook, especially in an otherwise complicated area like nuisance. Despite Coasean insights about causation and realist concerns about context, nuisance law contains a heavy strain of locational thinking - who acted so as to invade someone else's rights-and resembles the law of trespass in cases of substantial nuisances and nuisances per se. Injunctions are still a possible remedy for violations of this exclusion regime backed up by property rules.

But nuisance does more than reinforce the exclusion regime of trespass, because it supplements the basic exclusionary regime with 
rules of proper use. Where use conflict is high stakes and other methods of resolution, including private contracting and social norms, fail, nuisance can supply an off-the-rack scheme for proper use. Nuisance itself has largely given way to potentially more effective rules of proper use from other sources, such as pollution control and zoning. How extensive and detailed such rules of proper use should be is a difficult empirical question, but any legal solution must confront the question whether a governance scheme is worth incurring the costs of a partial withdrawal of the delegation to owners of use-decisions in the basic exclusionary regime. Courts face some but not all of the costs of setting up governance regimes, and those courts and commentators who focus on the benefits of governance have tended to downplay the importance of the lowcost exclusion rules. Interestingly, when it comes to implementation, courts have retained more of the exclusionary flavor of nuisance law than their nods to realism would indicate.

The information-cost theory shows why nuisance partakes both of the low-cost, low-precision exclusion regime characteristic of property generally, but also supplements-not replaces-this foundation of exclusion with fine-tuning through governance rules where stakes and transaction costs are high. But where courts face high information costs of delineating use rights, we expect a tendency towards exclusion even where stakes and private-party transaction costs are also high.

The view of nuisance as a hybrid between a foundation of exclusion and a superstructure of governance allows an explanation of the rarity of Calabresi and Melamed's Rule 4. The "Blackstonian" package of "entitlements" in the exclusion regime is supplemented by rules of proper use, which involve softening the harshness of injunctions and giving damages instead. If so, a pollution victim's right to exclude pollution is sometimes qualified and reduced to a right to compensation by damages under Rule 2, particularly where the nuisance is not substantial. But Rule 4 is not merely a relaxation of the exclusion regime. Under the basic ad coelum approach, the polluter does not have a "right" to pollute but rather a privilege to do so, indirectly protected by the right to exclude the world, including the victim, from its land. To give property rule protection to a "right" to pollute or even to soften such a "right" with a limitation to lesser liability rule protection, winds up elevating an undif- 
ferentiated privilege into a full-blown separately delineated right. A right in the polluter to pollute protected by a property rule or a liability rule undermines the exclusion-type ad coelum regime, and involves the high information costs characteristic of easements. And it is precisely under easements that the law has treated the exceptional situations in which polluters have acquired a "right" to pollute through transactions or prescription.

The difficult normative question presented by nuisance is a quite general one of when it makes sense to supplement a low-cost exclusion regime with governance rules, and when in particular courts are the best suppliers of such governance rules. In a range of situations including airplane overflights, building encroachments, and water, courts and other official institutions have at various times supplemented exclusion with governance. Particularly notorious has been the problem of oil and gas, in which parcel definition was inappropriate when a new dimension of the resource was discovered. I have suggested in this Article that courts' abilities to devise and administer their own governance regimes are quite limited and that the common law of oil and gas can be seen as a foundation upon which other legislative and administrative solutions were allowed to build. What the best feasible mix of judicial and other official efforts would have been is beyond the scope of this Article, but to blame the waste in the history of oil and gas development in the United States on the ad coelum rule is unwarranted.

Similarly, the problem of when to back off exclusion in the law of nuisance by reducing the protection of landowners' rights from property rule to liability rule has focused mostly on the benefits of judicial governance rules rather than on their information costs and the relative merits of other solutions. Cases like Boomer v. Atlantic Cement Co., that are heralded as the dawn of a more enlightened and realist approach to nuisance, ignore the benefits of exclusion and property rule protection. Moreover, the safety valves needed to mitigate the harsh impact of exclusion in the context of industrial pollution need not be all that large. In other areas in which exclusion has been attenuated with liability rules, legislative schemes with ex ante procedural safeguards have been quite common. Companies with needs for large parcels do sometimes assemble them consensually and where this is not possible, requiring them to justify the special need for a particular site ex ante at least allows 
the potential victims to point to alternatives before the question becomes one of shutting down an existing plant. Again, supplementation of exclusion with governance may be required but it should be undertaken cautiously and courts should be encouraged to take seriously the abilities of other institutions and actors, public and private, to supply governance more cost-effectively.

Seeing the exclusion element in nuisance as a second-order delegation to owners of first-order choices among an indefinite class of uses also allows us to explain nuisance law without committing to either corrective or utilitarian visions of tort law. The informationcost theory suggests that utilitarian and libertarian or corrective justice accounts of nuisance law would be closer to each other than previously thought.

Nuisance law seems like a mess because it is being asked to do something for which it is not suited. Nuisance is not the law of accident projected onto landowner disputes, and tort law is likewise not one grand governance scheme having as its domain all activities that figure in harmful conflicts. Rather, the information-cost theory suggests that certain things, very prominently among them land, are convenient focal points for clusters of use-privileges that need not be delineated or evaluated by officials under an exclusion regime. Nuisance is a governance regime resting on a foundation of exclusion. 


\section{$* * *$}

